Article

\title{
Predicting the Entrepreneurial Behaviour of Starting Up a New Company: A Regional Study Using PLS-SEM and Data from the Global Entrepreneurship Monitor
}

\author{
José Alberto Martínez-González ${ }^{1, *(\mathbb{D})}$, Carmen Dolores Álvarez-Albelo ${ }^{2}$ (D) Javier Mendoza-Jiménez ${ }^{1}$ (D) \\ and Urszula Kobylinska ${ }^{3}$ (D)
}

1 Department of Business Management and Economic History, Faculty of Economics, Business and Tourism, Universidad de La Laguna, 38200 Santa Cruz de Tenerife, Spain; jmendozj@ull.edu.es

2 Department of Economics, Accounting and Finance, Faculty of Economics, Business and Tourism, Universidad de La Laguna, 38200 San Cristóbal de La Laguna, Spain; calbelo@ull.edu.es

3 Faculty of Engineering Management, Bialystok University of Technology, 15-351 Bialystok, Poland; u.kobylinska@pb.edu.pl

* Correspondence: jmartine@ull.edu.es

Citation: Martínez-González, J.A.; Álvarez-Albelo, C.D.;

Mendoza-Jiménez, J.; Kobylinska, U. Predicting the Entrepreneurial Behaviour of Starting Up a New Company: A Regional Study Using PLS-SEM and Data from the Global Entrepreneurship Monitor.

Mathematics 2022, 10, 704. https:// doi.org/10.3390/math10050704

Academic Editor: Vicente

Coll-Serrano

Received: 2 February 2022

Accepted: 22 February 2022

Published: 23 February 2022

Publisher's Note: MDPI stays neutral with regard to jurisdictional claims in published maps and institutional affiliations.

Copyright: () 2022 by the authors Licensee MDPI, Basel, Switzerland. This article is an open access article distributed under the terms and conditions of the Creative Commons Attribution (CC BY) license (https:// creativecommons.org/licenses/by/ $4.0 /)$.

\begin{abstract}
It is essential to understand the variables that explain and predict the behaviour of starting up a new company in a regional context. This study aims to analyse the theoretical basis and predictive potential of the Global Entrepreneurship Monitor (GEM) data, considering the concerns and suggestions of other authors. In addition to an extensive literature review, a PLS-SEM methodology and data on variables and countries from the latest GEM report are used in this study. The results show that GEM reports have a sufficient theoretical foundation for quality studies in this field. In addition, a valid and reliable causal model is designed that includes all personal and contextual GEM variables. The hypotheses of the proposed model are based on the existing causal relationships in the literature, using GEM data in its formulation. The model is comprehensive and practical because it significantly predicts entrepreneurial behaviour, particularly entrepreneurial intention and action. The usefulness of this study is high, both for researchers, practitioners and institutions wishing to understand better and further promote entrepreneurial behaviour at a regional (country) level.
\end{abstract}

Keywords: Global Entrepreneurship Monitor; entrepreneurial behaviour; entrepreneurial intention; contextual variables of entrepreneurship; personal variables of entrepreneurship; regional entrepreneurship

MSC: 91B99

\section{Introduction}

The current importance of entrepreneurship has been highlighted by researchers and institutions related to start-ups [1,2]. Regarding the literature, recent studies find that the process of starting up a business plays a key role because it brings essential ingredients into the economic and sustainable development mix (e.g., jobs, income, etc.) [3,4]. At the institutional level, the Global Entrepreneurship Monitor report for 2020/2021 (www. gemconsortium.org, accessed on 21 June 2021) highlights that entrepreneurial activity is vital to all economies, arguably even more so after an economic and pandemic crisis [4,5]. For these reasons, entrepreneurship has become a key research topic in the world [6-8].

Specifically, entrepreneurship at the regional level has gained a special interest in recent years. This is because the contribution of entrepreneurship to regional development varies between regions, with the regional context regulating entrepreneurship in quantitative and qualitative terms [9-11]. In addition, entrepreneurship at the regional level is very stable because of the temporal stability of certain variables on which it depends (e.g., culture) [10-12]. 
Considering the critical role that entrepreneurs play in the process of creating new companies in the regional context, researchers and institutions linked to entrepreneurship are making efforts to identify the factors on which entrepreneurial behaviour depends [13-15]. First, the environmental factors (e.g., education) are the essential elements in the contextual approach. Second, regarding the human capital approach, studies have been conducted to know through certain perceptions the main attributes of the entrepreneur (e.g., attitude) [16-18]. Although both approaches have been widely used, the human capital approach stands out in the literature more than the contextual approach. Moreover, it should be noted that studies on entrepreneurship at the regional level that include both approaches together are scarce $[19,20]$.

In contrast to what happens at the institutional level, studies conducted by researchers on entrepreneurial behaviour at the regional level have aimed at designing causal predictive models, with descriptive studies being far less numerous [20-23]. Causal models are dominated by those aimed at predicting entrepreneurial intention, generally comprised of personal, non-contextual variables $[21,24]$. Researchers are interested in entrepreneurial intention because intention is the variable that best predicts the behaviour of creating a new company, which is considered a fundamental variable that is difficult to measure [24]. The causal models developed by authors to predict intention have received some criticism for not reflecting the complex nature of entrepreneurial behaviour and for their reduced predictive potential. Both criticisms are due, in part, to the limited number of variables they incorporate [20,25]. Due to this, other authors have emphasized the need to jointly introduce contextual and personal variables as well as new relationships in causal models [20,26]. In addition, causal models should make it possible to identify critical variables based on their impact on entrepreneurial behaviour and to differentiate between groups of countries according to criteria of interest [27]. Models should also incorporate, in addition to entrepreneurial intention, some variables that reflect the entrepreneur's actual behaviour when setting up a new venture [28,29]. This is because entrepreneurial behaviour is conceived as a combination of intention and action [1,2]. Finally, because researchers have difficulties in accessing quality global and periodic regional data when conducting their studies, the literature calls for the need to use trusted institutional sources specialized in obtaining such data [30].

Additionally, researchers are making increasing use of data in their studies on entrepreneurship at the country level, such as the data produced by the GEM since it was created in 1999 [20,31]. These reports have been recognized and used as some of the best sources of valid and reliable data to carry out comparative studies on entrepreneurship at the regional level $[29,32]$. However, it should be noted that GEM reports are descriptive, not predictive, and entrepreneurship intention is just another personal variable. Moreover, in GEM reports, entrepreneurship depends on contextual and personal variables, not just one or the other [28,33]. Despite the acknowledgement and growing use of GEM reports, several authors have suggested the need to study their theoretical foundation and predictive potential when used by researchers in the design of causal models $[34,35]$. Such a study should build on previous work in this field carried out by other authors, who have mainly used structural equation methodology $[35,36]$.

Given the above, this study has the following objectives:

1. To analyse, through a literature review, the theoretical foundation of GEM reports concerning the number, denomination, classification and content of the contextual and personal variables included in these reports.

2. To study, through the design of a causal model (PLS-SEM), the potential of GEM data to predict entrepreneurial behaviour at the regional level, i.e., entrepreneurial intention and action.

3. To determine, using a PLS-IPMA analysis, the critical and priority variables of GEM to predict entrepreneurial behaviour at the regional level.

4. To identify, through PLS-MGA (multi-group) analysis, whether there are causal differences between countries with high and low levels of TEA (Total Early stage En- 
trepreneurial Activity). TEA is chosen as the observed variable of interest related to the "action" of entrepreneurship. TEA is defined as the percentage of the population aged 18-64 who are either a nascent entrepreneur or an owner-manager of a new business.

This study is original and innovative. Firstly, the study is complete because a wide set of contextual and personal variables are included in the same study; it is usual to include only personal or contextual variables. The variables in this study are those that the GEM includes in its regular regional reports on entrepreneurship. Second, for the first time, a variable directly related to entrepreneurial behaviour (TEA) is included in a predictive study of entrepreneurship. Third, the proposed causal model is practical and useful because it allows predicting entrepreneurial behaviour at the country level using the data provided by the GEM. Fourth, the theoretical basis of the variables included in the GEM entrepreneurship model is analysed, an unprecedented task proposed by various authors. Lastly, the data are obtained during the COVID-19 pandemic, which allows for comparisons to be made when the same variables and relationships are studied once the pandemic is over.

\section{Literature Review}

\subsection{Variables Influencing Entrepreneurial Behaviour According to the Literature}

It is accepted in the literature on entrepreneurship at the regional level that entrepreneurs are the critical element in the process of creating a new venture. This is why entrepreneurship requires entrepreneurial behaviour (intention and action) [1,2,30]. In turn, it has been found that entrepreneurial behaviour depends on contextual variables and personal variables, the latter having been more studied [37,38].

Their importance is very high regarding contextual variables considering that entrepreneurial behaviour develops in a specific context, although some contextual variables are more favourable than others $[39,40]$. Contextual variables are often classified in the literature as formal institutional variables and informal institutional variables. From a formal institutional perspective, the importance of government policies and programmes, as well as infrastructures (e.g., physical, commercial, technological and financial), market development and innovation transfer is highlighted [41,42]. The role of the education system has also been emphasized in the literature because it enables the development of entrepreneurial vocation, values related to self-employment, skills to create a business and entrepreneurial intention [42-44]. Regarding the informal institutional variables that influence entrepreneurial behaviour, the literature underlines the role of culture, which develops over time through the adoption and internalisation, usually unconsciously, of norms, beliefs, practices and customs [45]. In particular, it has been found that cultural diversity can help to explain regional differences in entrepreneurship, as the decision to start a new venture depends on the cultural context in which it takes place [46,47]. Individualistic cultures have also been found to be more conducive to entrepreneurship than collectivistic cultures, as, in the former, people consider their interests before those of the group $[48,49]$.

Regarding the personal variables linked to entrepreneurial behaviour, the literature highlights entrepreneurial intention, which is the variable that best predicts the behaviour of creating a new company at the regional level [50,51]. For these reasons, intention is the central variable in most studies on entrepreneurial behaviour, most of which aim to design causal models to predict it. The remaining personal variables, and occasionally some contextual variables, constitute the independent variables in such causal models [52-54]. Regarding its definition, entrepreneurial intention is conceived as an entrepreneur's propensity to make an intentional, deliberate and planned decision to create a new venture [53,55].

Two of the most widely used models in the literature to predict entrepreneurial intention are Shapero and Sokol's [56] entrepreneurial event model (EEM) and Ajzen's [57] theory of planned behaviour (TPB) [20,58]. In the model by Shapero and Sokol, entrepreneurial intention depends on three variables: perceived desirability, which derives from a perceived 
reasonable business opportunity; perceived feasibility, based on the perception of one's capabilities; and propensity to act $[59,60]$. However, it is the TPB model that predominates in the literature due to its higher predictive power [61,62]. The TPB model's intention to start a new venture depends on the attitude towards entrepreneurship, perceived control and subjective norm [53,63]. Attitude corresponds to desirability, included in the EEM model, and is defined as the personal valuation about being an entrepreneur $[53,63]$. Regarding perceived behavioural control, this is a variable similar to perceived feasibility in the Shapero and Sokol model and is defined as an individual's assessment of the extent to which they can perform a specific behaviour $[53,63,64]$. Perceived control is a construct closely related to self-efficacy, defined as the belief in resources and competencies to achieve one's goals $[65,66]$. Finally, subjective norms refer to how the subject himself perceives that his behaviour will be accepted by his belonging or reference group [53,62]. The influence of subjective norms is similar to the process of entrepreneurial role adoption by the subject that she or he observes in a known person or a family member, which largely explains the succession process $[67,68]$.

Despite the many studies conducted and the findings obtained, the literature points out the limitations of existing causal models in predicting complex entrepreneurial behaviour in a regional context. It is mainly due to the small number of variables they incorporate $[69,70]$. On the other hand, the authors of predictive behavioural studies need quality traditional data sources for a wide range of variables and countries [30]. In order to respond to these demands, several authors suggest enriching predictive models by incorporating new variables and new relationships, as well as variables that, together with intention, reflect effective entrepreneurial behaviour [71]. To study more deeply the quality of data from institutional data sources has also been suggested [71-73]. It is precisely in this context that the possibility of designing causal models using data from GEM reports has been raised in the literature, once their theoretical foundation and statistical significance has been confirmed [74-76].

\subsection{Variables Influencing Entrepreneurial Behaviour at the Institutional Level: The Case of the Global Entrepreneurship Monitor}

According to the GEM, the decision to start a new business depends on a broad set of personal and contextual variables, all of which are equally important (Table 1) [5]. Despite their equal importance, in GEM reports, contextual variables can influence personal variables, although GEM does not specify the nature of this relationship [28,77]. Moreover, as mentioned above, in GEM reports, entrepreneurial intention is just another personal variable $[5,30]$.

Table 1. Contextual and personal variables of entrepreneurship. Comparison between the literature and the Global Entrepreneurship Monitor proposal.

Entrepreneurship Variables in the Literature

(b) Contextual Variables

Government policies and programmes

Infraestructures

Market development

Education

Entrepreneurial Finance

R\&D Transfer

Culture
Entrepreneurship Variables in the Global Entrepreneurship

(b) Entrepreneurial Framework Conditions

Governmental Policies: Support and Relevance

Government Policies: Taxes and Bureaucracy

Government Entrepreneurship Programmes Commercial and Legal Infrastructure

Physical Infrastructure

Internal Market Dynamics

Internal Market Openess

Entrepreneurial Education at the School Stage

Entrepreneurial Education at the Post-School Stage

Entrepreneurial Finance

R\&D Transfer

Cultural and Social Norms 
Table 1. Cont.

Entrepreneurship Variables in the Lit
(a) Personal variables
Entrepreneurial Intention
Attitude
Perceived behavioural control
Subjective norm
Motivation
Personal values
Personality
Competencies

Family role adoption
Entrepreneurship Variables in the Global Entrepreneurship

(a) Entrepreneurial behaviour and attitudes indicators

Entrepreneurial Intentions

Perceived Capabilities

Ease of Starting a Business

Innovative Capacity

High Status to Successful Entrepreneurs

Entrepreneurship as a Good Career Choice

\author{
Perceived Opportunities \\ Vision \\ Fear of Failure
}

Knowing a Startup Entrepreneur

The contextual variables are considered an essential part of business creation and directly influence entrepreneurial opportunities, competencies, and preferences. The source of information on these variables is the National Experts Survey, a standard GEM methodology to capture expert judgments to evaluate regional variables [5,30]. Regarding their measurement, the values of the contextual variables represent the average scalar data per country that come from the responses of entrepreneurship experts to specially designed questionnaires. Regarding personal variables, the information is obtained by GEM through the design and application of the Adult Population Survey (APS), a unique and comprehensive questionnaire administered to a minimum of 2000 adults in each GEM country. All personal variables included in GEM reports refer to average percentages of the population aged 18-64 by country and are based on the perceptions and statements of the population $[5,30]$.

Finally, it should be noted that GEM reports also provide several outcome variables or indicators directly or indirectly related to entrepreneurship. This study has included the TEA (Total Early stage Entrepreneurial Activity) indicator, the most critical outcome indicator in the GEM reports [5]. GEM defines TEA as the percentage of the population aged 18-64 who are either a nascent entrepreneur or an owner-manager of a new business. Its inclusion in this study responds to suggestions by several authors to include in causal models, along with entrepreneurial intention, some variable that reflects the "action" inherent to entrepreneurial behaviour [28,29]. Moreover, TEA will be the variable used in this study to achieve objective 4 .

As stated in objective 1 of this study, the theoretical foundation of GEM variables can be analysed by reviewing the literature above and making use of the information in Table 1. Table 1 lists the contextual and personal variables related to entrepreneurial behaviour included in GEM reports and the variables proposed in the literature. The analysis of the theoretical underpinning of GEM reports is concerned with the similarity between the two sets of variables and is presented in the Results Section of this study. In particular, these results will be related to the number, denomination, classification and content of the variables, as recently performed by other authors [30].

In the next section, the hypotheses and the causal model proposed in this study are presented. The results in the next section also help to test the theoretical foundation of GEM reports insofar as the hypotheses of the proposed model are based on the causal relationships tested by other authors.

\section{Hypotheses and Model Development}

The hypotheses and the predictive model proposed in this study are presented below. The model has been designed to consider the contributions of other authors in this field and use GEM variables and country data. 
First, it has been found in the literature that entrepreneurial behaviour depends on contextual or environmental factors, which in turn influence personal variables [20,78]. Among the environmental factors that influence entrepreneurship culture and education stand out $[79,80]$. Regarding culture, it refers to the social value structure of a community or region [81,82]. It should be noted that culture carries social legitimacy. Therefore, to the extent that a culture values entrepreneurship, it will be highly valued and socially accepted, thus creating a favourable and supportive context for entrepreneurship $[45,83,84]$.

On the other hand, education always considers the current socio-economic context, including the entrepreneurial field. Through educational design and practice, education tries to adapt to this context, and/or it will try to drive the changes and improvements that the context requires $[85,86]$. In particular, it has been confirmed that culture and education directly influence the intention and action to create a new venture, and indirectly through the subject's perceptions about the entrepreneurial context, in particular about the basic infrastructures for entrepreneurship $[87,88]$. Considering the above, the first two hypotheses state:

Hypothesis 1 (H1). According to GEM data, education and culture related to entrepreneurship directly and positively influence entrepreneurial intention and action.

Hypothesis 2 (H2). According to GEM data, education and culture related to entrepreneurship directly and positively influence the perception of basic infrastructures for entrepreneurship.

Government policies and programmes to foster entrepreneurship at the regional level do not originate in a vacuum, but through interaction with the context $[89,90]$. It has been found in the literature that such policies and programmes depend on demands related to the degree of adequacy of the physical, technological, financial and commercial infrastructures needed for entrepreneurship and existing in the region [91,92]. It is one of the missions and social responsibilities of governments to facilitate the existence of a favourable context for entrepreneurship, improving access to finance and developing appropriate taxation, among other measures, all within the limits of their capabilities, principles and political inclination [92-94]. It should be noted that, as in the private sector, the satisfaction of the needs, wants, and expectations of the recipients and beneficiaries of government policies have an impact on the perception of those policies, the reputation of the issuing organisation and the loyalty to it $[95,96]$. So much so that governments and the public sector are using tools from the private sector to improve the adaptation of their policies to the context, such as market orientation $[91,97,98]$. Considering the above, the following hypothesis is expressed as follows:

Hypothesis 3 (H3). According to GEM data, perceptions about infrastructures and primary conditions for entrepreneurship directly and positively influence perceptions about government policies and programmes related to entrepreneurship.

The influence of government policies and programmes on people's perceptions, in whatever domain they are targeted (e.g., health and education), is due to both internal subject and external factors [99,100]. In particular, perceptions of government policies and programmes related to entrepreneurship, including those related to innovation, have been shown to influence perceptions of entrepreneurship opportunity and the ease of undertaking entrepreneurship [80,101,102]. Such perceptions, which indirectly and positively influence entrepreneurial intention and action, are essential in the early stages of entrepreneurship [103-105]. Entrepreneurs are risk takers (e.g., financial risks) and sensitive to institutional support or disincentive, whether real or only perceived. Thus, subjects who perceive opportunity and ease of entrepreneurship (e.g., legislative, governmental, and commercial) possess greater entrepreneurial intention and action. Their confidence, hope, and dispositional optimism are higher when the perceived risk is lower $[59,103,104]$. Given the above, the following hypothesis states: 
Hypothesis 4 (H4). According to GEM data, perceptions about government policies and programmes on entrepreneurship positively and directly influence perceptions about entrepreneurial opportunities and facilities.

Subjective norm is defined as the belief that people close to the subject (e.g., family and friends) might accept or reject a particular behaviour $[20,57,106]$. Therefore, the subjective norm represents a code of conduct that prescribes or prohibits behaviour in members of a group [107,108]. Concerning antecedents, in the context of entrepreneurship, the perception of how contextual factors facilitate entrepreneurship has been shown to directly or indirectly influence subjective norm formation [20,109,110]. It should be noted that the influence of perceptions and the power of the subjective norm is particularly relevant within the group of people whose influence contributes to maintaining perceptions and the subjective norm [110-112]. Such influence is more significant when there are favourable expectations regarding the attainment of benefits from entrepreneurship and when the subject possesses a high self-concept of an entrepreneur $[113,114]$. Therefore, the following hypothesis stipulates that:

Hypothesis 5 (H5). According to GEM data, perceptions about entrepreneurial opportunities and facilities directly and positively influence subjective norms.

Values represent a person's predisposition toward an object or behaviour, in this case, the behaviour of starting a new venture $[115,116]$. Values are criteria for action at the origin of any behaviour, are highly stable and are formed during the socialisation process $[117,118]$. There are many personal value categories associated with entrepreneurship, and some authors claim that entrepreneurs can be differentiated from each other solely based on their value structure [118,119]. Regarding the antecedents of personal values, the subjective norm has been found to influence their formation directly due to the motivational component that values possess $[120,121]$. It has been shown that people adopt values when they perceive that other significant agents share these values [110,120,122]. Thus, values represent the result of the subject's self-adjustment effort to a social context $[123,124]$. Based on the above, the following hypothesis states:

Hypothesis 6 (H6). According to GEM data, the subjective norm directly and positively influences values related to entrepreneurship.

Values influence a multitude of variables. For example, it has been confirmed by several authors that personal values influence self-efficacy and other related constructs, such as perceived control, the belief in personal agency and the competencies perceived by the subject, in this case, the entrepreneur $[123,125]$. Particularly in the field of entrepreneurship, it has been shown that people who possess pro-entrepreneurship values, which depend on the subjective norm, are considered competent and self-efficacious in entrepreneurship [126,127]. Self-efficacy is a central concept in the context of entrepreneurship. It is defined as an individual's belief or confidence in his or her competence to mobilise the resources and activities necessary to successfully execute a specific task within a given context [126-128]. The relationship between personal values and self-efficacy occurs within a motivational process of confirming attitudes, beliefs, perceptions and expectations, particularly in cultures that value and reward individual performance and achievement $[127,129,130]$.

Hypothesis 7 (H7). According to GEM data, personal values related to entrepreneurship directly and positively influence entrepreneurial self-efficacy.

Entrepreneurial self-efficacy is the best predictor of entrepreneurial intention and startup behaviour [131-133]. It is a motivational and adequate antecedent of entrepreneurial intention and behaviour regardless of the regional level $[127,134]$. Self-efficacy enables the 
entrepreneur to overcome challenges when starting up a business and use the negative feedback they receive to improve their performance in that process $[127,135,136]$.

Hypothesis 8 (H8). According to GEM data, self-efficacy directly and positively influences entrepreneurial intention and start-up behaviour.

Figure 1 presents the model proposed in this study. The model is in line with other models recently developed in the literature [20,108]. As proposed by the GEM and other authors, the model represents a unidirectional sequential path from contextual variables to personal variables, culminating in entrepreneurial intention and action [28,137]. The model starts with three contextual variables: "Education and culture", "Basic structure", and "Politics and programmes". These contextual variables, directly and indirectly, influence the "Ease and opportunity perception" variable, which connects the contextual variables with the personal variables ("Subjective norm", "Personal values", and "Personal selfefficacy"). The variable "Personal self-efficacy" is the one that directly influences the latent dependent variable, "Entrepreneurship intention and action".

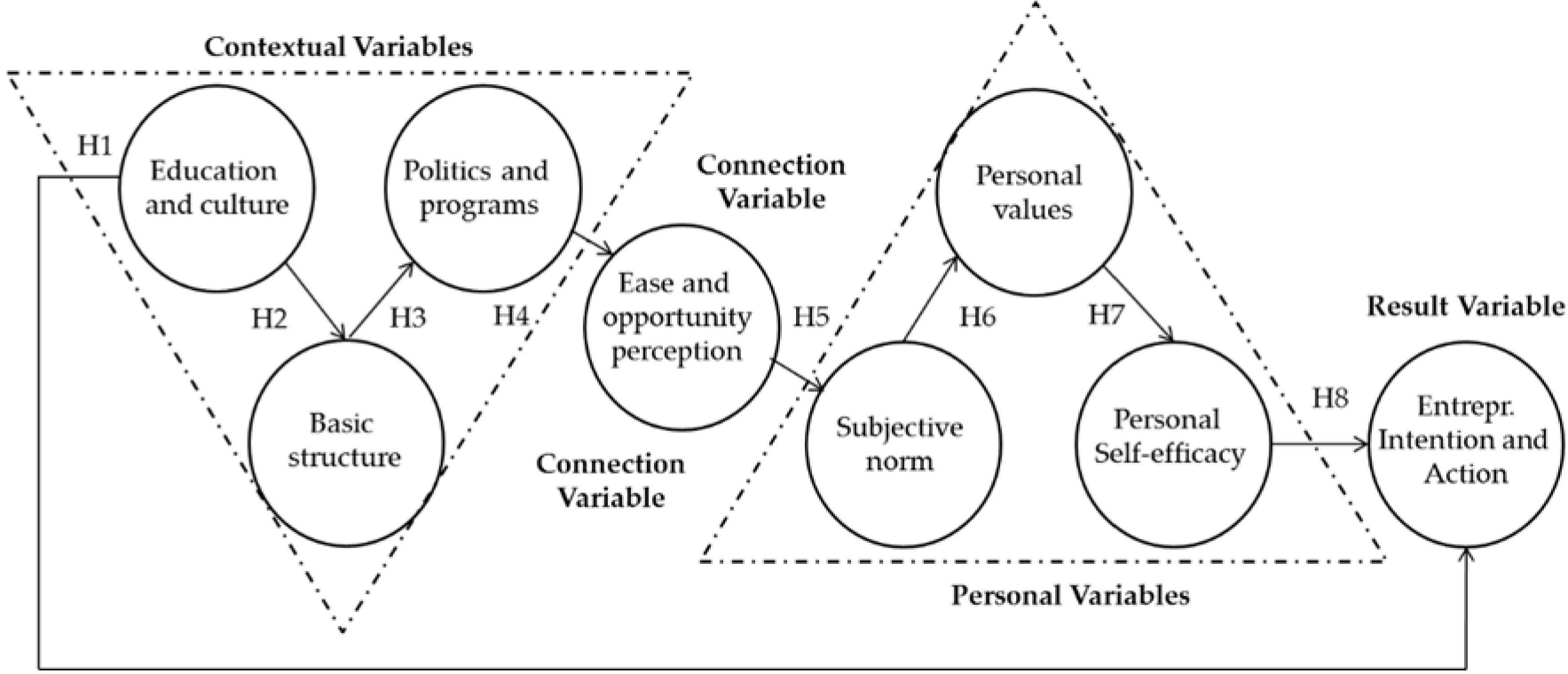

Figure 1. Research proposed model. Source: Authors.

\section{Research Methodology}

\subsection{Data Collection and Sample Profile}

Data were obtained from the Global Entrepreneurship Monitor platform (www. gemconsortium.org, accessed on 23 June 2021), similar to other authors [30,138]. Specifically, the information included in the databases available in Excel for 2020 werew used, which is the latest data available on the GEM website when this study was carried out (www.gemconsortium.org, accessed on 25 June 2021). The 45 countries $(\mathrm{N}=45)$ for which data were available for all variables included in this study were selected. It should be noted that the effort and rigour of data collection for GEM that has occurred every year mean this dataset has received a significant amount of respect across the social sciences [138,139]. Finally, the high validity, reliability and unidimensionality of the GEM data have recently been confirmed through the Rasch mathematical model [30].

\subsection{Variables and Constructs}

First, the observed personal and contextual variables used in this study were included in the latest GEM report 2020-2021 (www.gemconsortium.org, accessed on 25 June 2021), and are explained in Section 2.2. (Table 2). In addition, the TEA (Total early stage En- 
trepreneurial Activity) indicator was selected as an outcome variable. Second, to identify the latent variables or constructs, an exploratory factor analysis was carried out. This analysis was carried out using the principal components extraction method and the Varimax rotation with Kaiser normalization, as performed by other authors [20]. After the analyses, eight latent variables (factors) were obtained (Table 2). The sum of the squared loads of the rotation explained $87.28 \%$ of the variance accumulated through the eight resulting factors (Appendix A). These variables were Education and Culture (ECU), Basic Infrastructures (BIN), Government Policies and Programmes (GPP), Perceptions (PER), Subjective Norm (SUN), Personal Values (PVA), Self-efficacy (SEF) and Entrepreneurial Intention and Action (EIA). Two observed variables were eliminated through this factor analysis: Fear of Failure (personal variable) and Internal Market Dynamics (Contextual variable). Additionally, the reliability changed from 0.86 to 0.89 by eliminating these variables. Only two items in five latent variables were accepted because these items had a low correlation with other latent variables, and the correlation between the items belonging to the same variable was greater than $70 \%$ [140].

Table 2. Descriptive Data. Contextual and Personal Variables.

\begin{tabular}{|c|c|c|c|c|}
\hline Constructs and Variables & $\sum_{\geq 50}$ & $\begin{array}{c}\% \\
\geq 50 \%\end{array}$ & $\begin{array}{c}\text { Average } \\
\geq 3.00\end{array}$ & $\begin{array}{c}\text { SD } \\
\leq 1.50 / \leq 25 \%\end{array}$ \\
\hline \multicolumn{5}{|l|}{ (a) Contextual Variables } \\
\hline \multicolumn{5}{|l|}{ Construct ECU: Education and Culture } \\
\hline CES: Entrepreneurial Education at the School Stage & 111.00 & $44.40 \%$ & 2.22 & 0.45 \\
\hline CPE: Entrepreneurial Education at the Post-School Stage & 144.70 & $57.88 \%$ & 2.89 & 0.36 \\
\hline CSN: Cultural and Social Norms & 151.57 & $60.63 \%$ & 3.03 & 0.53 \\
\hline \multicolumn{5}{|l|}{ Construct BIN: Basic Infrastructures } \\
\hline CEF: Entrepreneurial Finance & 139.20 & $55.68 \%$ & 2.78 & 0.42 \\
\hline CLI: Commercial and Legal Infrastructure & 150.49 & $60.20 \%$ & 3.01 & 0.35 \\
\hline CMO: Internal Market Openness & 135.87 & $54.35 \%$ & 2.72 & 0.34 \\
\hline CPI: Physical Infrastructure & 186.88 & $74.75 \%$ & 3.74 & 0.45 \\
\hline \multicolumn{5}{|l|}{ Construct GPP: Government Policies and Programmes } \\
\hline CGP: Government Entrepreneurship Programmes & 138.94 & $55.58 \%$ & 2.78 & 0.46 \\
\hline CRD: R\&D Transfer & 128.17 & $51.27 \%$ & 2.56 & 0.41 \\
\hline CSR: Governmental Policies: Support and Relevance & 135.74 & $54.30 \%$ & 2.71 & 0.49 \\
\hline \multicolumn{5}{|l|}{ (b) Personal Variables } \\
\hline \multicolumn{5}{|l|}{ Construct PER: Perceptions } \\
\hline PES Ease of Starting a Business & 2510.20 & $50.20 \%$ & 50.20 & 18.60 \\
\hline PPO Perceived Opportunities & 2682.30 & $53.65 \%$ & 53.65 & 15.44 \\
\hline \multicolumn{5}{|l|}{ Construct SUN: Subjective Norm } \\
\hline PIC Innovativy Capacity & 2650.30 & $53.00 \%$ & 53.01 & 14.41 \\
\hline PKS Knowing a Startup Entrepreneur & 2655.80 & $53.12 \%$ & 53.12 & 11.98 \\
\hline \multicolumn{5}{|l|}{ Construct PVA: Personal Values } \\
\hline PCC Entrepreneurship as a Good Career Choice & 3282.89 & $65.66 \%$ & 65.66 & 16.91 \\
\hline PHS High Status to Successful Entrepreneurs & 3646.15 & $72.92 \%$ & 72.92 & 15.77 \\
\hline \multicolumn{5}{|l|}{ Construct SEF: Selfefficacy } \\
\hline PPC Perceived Capabilities & 2913.57 & $58.27 \%$ & 58.27 & 13.89 \\
\hline PVI Vision & 3098.60 & $61.98 \%$ & 61.97 & 16.28 \\
\hline \multicolumn{5}{|l|}{ Construct EIA: Entrepreneurial Intention and Action } \\
\hline PEI Entrepreneurial Intention & 1185.75 & $23.72 \%$ & 23.72 & 15.65 \\
\hline TEA Total Early stage Entrepreneurial Activity & 640.69 & $12.81 \%$ & 12.81 & 7.14 \\
\hline
\end{tabular}

CRC: correlations of the rotating components (Factorial analysis).

\subsection{Methodology}

Firstly, data were examined using the SPSS-25 programme to obtain descriptive indicators. The Partial Least Squares Structural Equation Modelling (PLS-SEM) method was applied through SmartPLS-3 software (3.3.2 version) to minimize the residual variances of the endogenous variable. PLS was selected due to its potential to explain the theory and 
predict human behaviour [141]. In addition, PLS allows the use of a wide range of sample sizes and reflective variables, and it shows more reliable results and does not require a normal distribution of data [141].

The PLS-SEM approach implies studying the measurement model and the study of the structural model. The Measurement and Structural models take the general form as follows:

$$
\begin{gathered}
\text { Measurement model: } X=C^{\prime} Y+\varepsilon \\
\text { Structural model: } Y=B^{\prime} Y+\zeta
\end{gathered}
$$

where:

$\mathrm{X}$ is a $\mathrm{J}$ by 1 vector of indicators;

$\mathrm{Y}$ is a $\mathrm{P}$ by 1 vector of latent variables;

$\mathrm{C}$ is a $\mathrm{P}$ by $\mathrm{J}$ matrix of loadings;

$\mathrm{B}$ is a $\mathrm{P}$ by $\mathrm{P}$ matrix of path coefficients;

$\varepsilon$ is a $\mathrm{J}$ by 1 vector of the residuals of indicators;

$\zeta$ is a $\mathrm{P}$ by 1 vector of the residuals of latent variables.

The reflective indicators in the latest GEM report 2020-2021 (www.gemconsortium.org, accessed on 25 June 2021) were used in the study. These are reflective indicators because they meet the criteria proposed by Jarvis, MacKenzie and Podsakoff [142]. As proposed by other authors, an Importance-Performance Analysis (IPMA) and Multigroup Technique were included in this study to achieve objectives 3 and 4, respectively [20,143]. Finally, it should be noted that the ultimate guidelines in applying PLS-SEM in research were followed in the application of PLS-SEM [141,144].

\section{Results and Discussion}

As is usual in studies of this nature, descriptive results will be presented first [20]. Following the suggestions of other authors, this will be followed by the results according to the study's objectives and the hypotheses set out in the model proposed in this paper [30].

\subsection{Descriptive Data}

Firstly, it should be noted that, in the GEM data, contextual variables are assessed using Likert-type scales, and personal variables refer to percentages of the population. Converting the total score of each observed variable $\left(\sum\right)$ into percentages $(\%)$ (Table 2$)$ allows us to homogenise and relativise the results. The percentages refer to the score obtained by each variable compared to the maximum value that the variable would have reached had all countries obtained the maximum value. As shown in Table 2, most of the GEM contextual and personal variables obtained scores similar to and above $50 \%$ of the maximum possible score $(100 \%)$. The lowest scoring contextual variable is CES (Entrepreneurial Education at School Stage) $(\mathrm{CES}=44.40 \%)$, while CPI (Physical Infrastructure) is the highest scoring variable (CPI $=74.75 \%)$.

Regarding the personal variables, PHS (High Status to Successful Entrepreneurs) is the one with the highest score (PHS $=72.92 \%$ ), and PEI (Entrepreneurial Intention) is the one with the lowest score (PEI $=23.72 \%$ ). Finally, TEA (Total Early stage Entrepreneurial Activity) is the lowest score of the variables (TEA $=12.81 \%)$. The low percentages of entrepreneurial intention and the TEA variable, which represent the dependent construct of this study, are related to their nature or content. Finally, the standard deviation shows no extreme values within the data distribution.

\subsection{Results Related to Objective 1: A Study of the Theoretical Basis of GEM Variables}

The literature analysis carried out in this study confirms the theoretical basis of GEM variables, an analysis requested by other authors [34]. The high degree of parallels in the number of variables, their classification, naming and content between the variables proposed by other authors and those included in GEM reports is confirmed. These results are in line with recent findings [30] and are crucial, considering the increasing number of 
quality studies on entrepreneurship at the country level using GEM data [31]. In particular, Martínez-González, Kobylinska and Gutiérrez-Taño [30] have verified the validity and reliability of the GEM data using the Rasch model.

\subsection{Results Related to Objective 2: Study the Predictive Potential of the Proposed Causal Model Using GEM Data}

It is necessary to carry out three consecutive processes or sub-models to study the predictive potential of a causal model in a PLS-SEM context. Firstly, the study of the measurement and the structural models, and secondly, the analysis of the predictive potential itself $[141,144]$. A global fit analysis of the model designed in the PLS-SEM context is not considered necessary beforehand due to such models' stability when small samples are used [79,139]. Finally, the PLS-SEM approach does not have problems with the convergence that affects CB-SEM [141,144].

\subsubsection{Testing the Measurement Model}

The analysis of the measurement model involves testing the individual and composite reliability and the convergent and discriminant validity. First, regarding individual and composite reliability, the results show that all observed variables and constructs reached the adequate level $(\lambda>0.700 ; C R>0.700)$ (Table 3$)$. Thus, it can be said that the measurement model is internally consistent [144]. The following general form expresses CR:

$$
\mathrm{CR}=\frac{\left(\sum_{\mathrm{k}=1}^{\mathrm{k}} \mathrm{l}_{\mathrm{k}}\right)^{2}}{\left(\sum_{\mathrm{k}=1}^{\mathrm{k}} \mathrm{l}_{\mathrm{k}}\right)^{2}+\sum_{\mathrm{k}=1}^{\mathrm{k}} \operatorname{var}\left(\mathrm{e}_{\mathrm{k}}\right)}
$$

where $l_{k}$ is the outer loading of the manifest variable $k$ corresponding to a latent variable measured with $\mathrm{K}$ indicators; $\mathrm{e}_{\mathrm{k}}$ is the measurement error of $\mathrm{k}$; and $\operatorname{var}\left(\mathrm{e}_{\mathrm{k}}\right)$ corresponds to the measurement error variance.

Table 3. Measurement model data.

\begin{tabular}{|c|c|c|c|c|c|}
\hline Constructs and Observed Variables & $\begin{array}{c}\lambda \\
>0.700\end{array}$ & $\begin{array}{c}\mathrm{CR} \\
>0.700\end{array}$ & $\begin{array}{c}\text { AVE } \\
>0.500\end{array}$ & $\begin{array}{c}\mathrm{R}^{2} \\
>0.500\end{array}$ & $\begin{array}{c}Q^{2} \\
>0.000\end{array}$ \\
\hline (a) Contextual Variables & & \multirow{6}{*}{0.909} & \multirow{6}{*}{0.768} & \multirow{6}{*}{ - } & \multirow{7}{*}{ - } \\
\hline Construct ECU: Education and Culture & & & & & \\
\hline CES: Entrepreneurial Education at the School Stage & 0.898 & & & & \\
\hline CPE: Entrepreneurial Education at the Post-School Stage & 0.854 & & & & \\
\hline CSN: Cultural and Social Norms & 0.877 & & & & \\
\hline Construct BIN: Basic Infrastructures & & & & & \\
\hline CEF: Entrepreneurial Finance & 0.866 & \multirow{4}{*}{0.924} & \multirow{4}{*}{0.753} & \multirow{4}{*}{0.571} & \\
\hline CLI: Commercial and Legal Infrastructure & 0.880 & & & & \multirow{3}{*}{0.412} \\
\hline CMO: Internal Market Openness & 0.915 & & & & \\
\hline CPI: Physical Infrastructure & 0.804 & & & & \\
\hline Construct GPP: Government Policies and Programmes & & \multirow{5}{*}{0.951} & \multirow{5}{*}{0.828} & & \multirow{5}{*}{0.577} \\
\hline CGP: Government Entrepreneurship Programmes & 0.934 & & & \multirow{4}{*}{0.711} & \\
\hline CRD: R\&D Transfer & 0.911 & & & & \\
\hline CSR: Governmental Policies: Support and Relevance & 0.927 & & & & \\
\hline $\begin{array}{l}\text { CTB: Government Policies: Taxes and Bureaucracy } \\
\text { (b) Personal Variables }\end{array}$ & 0.866 & & & & \\
\hline Construct PER: Perceptions & & \multirow{3}{*}{0.890} & \multirow{3}{*}{0.803} & \multirow{3}{*}{0.156} & \multirow{3}{*}{0.130} \\
\hline PES Ease of Starting a Business & 0.820 & & & & \\
\hline PPO Perceived Opportunities & 0.967 & & & & \\
\hline Construct SUN: Subjective Norm & & \multirow{4}{*}{0.835} & \multirow{4}{*}{0.718} & \multirow{4}{*}{0.196} & \multirow{4}{*}{0.138} \\
\hline PIC Innovativy Capacity & 0.899 & & & & \\
\hline PKS Knowing a Startup Entrepreneur & 0.793 & & & & \\
\hline Construct PVA: Personal Values & & & & & \\
\hline PCC Entrepreneurship as a Good Career Choice & 0.943 & \multirow{2}{*}{0.889} & \multirow{2}{*}{0.801} & \multirow{2}{*}{0.384} & \multirow{2}{*}{0.158} \\
\hline PHS High Status to Successful Entrepreneurs & 0.844 & & & & \\
\hline
\end{tabular}


Table 3. Cont.

\begin{tabular}{|c|c|c|c|c|c|}
\hline Constructs and Observed Variables & $\begin{array}{c}\lambda \\
>0.700\end{array}$ & $\begin{array}{c}\text { CR } \\
>0.700\end{array}$ & $\begin{array}{c}\text { AVE } \\
>0.500\end{array}$ & $\begin{array}{c}R^{2} \\
>0.500\end{array}$ & $\begin{array}{c}\mathrm{Q}^{2} \\
>0.000\end{array}$ \\
\hline $\begin{array}{c}\text { Construct SEF: Selfefficacy } \\
\text { PPC Perceived Capabilities } \\
\text { PVI Vision }\end{array}$ & $\begin{array}{l}0.932 \\
0.929\end{array}$ & 0.928 & 0.866 & 0.380 & 0.213 \\
\hline $\begin{array}{c}\text { Construct EIA: Entrepreneurial Intention and Action } \\
\text { PEI Entrepreneurial Intention } \\
\text { TEA Total Early stage Entrepreneurial Activity }\end{array}$ & $\begin{array}{l}0.869 \\
0.852\end{array}$ & 0.851 & 0.740 & 0.546 & 0.319 \\
\hline
\end{tabular}

Second, the convergent validity was confirmed because the AVE values (average variance extracted) were more significant than 0.500 [141]. The following general form expresses AVE:

$$
\mathrm{AVE}=\frac{\sum_{\mathrm{k}=1}^{\mathrm{k}} \mathrm{l}_{\mathrm{k}}^{2}}{\mathrm{~K}}
$$

where $l_{k}$ is the outer loading of the manifest variable $k$ corresponding to a latent variable measured with $\mathrm{K}$ indicators.

Discriminant validity was verified because the square root of the AVE of each variable (data in bold in Table 4) was greater than the variance shared with the other variables (values below the diagonal in Table 4) [145]. In addition, values of the heterotrait-monotrait ratio (HTMT) (values above the diagonal in Table 5) were lower than 0.85 in all cases [141]. It should be noted that the overall validity and reliability of the data included in GEM reports (not of a specific causal model) have already been confirmed in a previous study using the Rasch mathematical model [30].

Table 4. Discriminant validity.

\begin{tabular}{ccccccccc}
\hline Constructs & ECU & BIN & GPP & PER & SUN & PVA & SEF & EIA \\
\hline ECU: Education and Culture & $\mathbf{0 . 8 7 6}$ & 0.848 & 0.816 & 0.503 & 0.247 & 0.307 & 0.117 & 0.158 \\
BIN: Basic Infrastructures & 0.756 & $\mathbf{0 . 8 6 7}$ & 0.810 & 0.406 & 0.228 & 0.187 & 0.398 & 0.429 \\
GPP: Government Policies and Programmes & 0.779 & 0.843 & $\mathbf{0 . 9 1 0}$ & 0.316 & 0.283 & 0.228 & 0.266 & 0.198 \\
PER: Perceptions & 0.386 & 0.287 & 0.236 & $\mathbf{0 . 8 9 6}$ & 0.335 & 0.554 & 0.313 & 0.234 \\
SUN: Subjective Norm & 0.057 & -0.190 & -0.159 & 0.311 & $\mathbf{0 . 8 4 7}$ & 0.724 & 0.825 & 0.812 \\
PVA: Personal Values & 0.232 & 0.061 & 0.062 & 0.492 & 0.533 & $\mathbf{0 . 8 9 5}$ & 0.622 & 0.539 \\
SEF: Self efficacy & -0.080 & -0.346 & -0.241 & 0.269 & 0.757 & 0.529 & $\mathbf{0 . 9 3 0}$ & 0.833 \\
EIA: Entrepr. Intention and Action & 0.042 & -0.346 & -0.159 & 0.117 & 0.576 & 0.412 & 0.673 & $\mathbf{0 . 8 6 0}$ \\
\hline
\end{tabular}

\subsubsection{Testing the Structural Model}

Regarding the relationship between the constructs or latent variables, which the structural model shows, it was firstly verified that all the relationships had the same positive sign as their hypotheses. Additionally, it was confirmed that all path coefficients $(\beta)$ (standardized regression weights) reached the minimum acceptable level $(\beta \geq 0.2)$ [146] (Table 5). Except for one relationship, all others reached the optimal level $(\beta \geq 0.3)$ [147]. The relationship corresponding to hypothesis $1(\mathrm{H} 1)$ obtained the lowest value $\left(\beta_{\mathrm{H} 1}=0.210\right.$, $t$-value $=3.330, p=0.030)$. By contrast, the relationship corresponding to hypothesis $3(\mathrm{H} 3)$ obtained the highest value $\left(\beta_{\mathrm{H} 3}=0.843, t\right.$-value $\left.=25.894, p=0.000\right)$. It was followed in magnitude by hypothesis $8(\mathrm{H} 8)\left(\beta_{\mathrm{H} 8}=0.680, t\right.$-value $\left.=12.036, p=0.000\right)$. The results show that all the direct relationships reached high significance $(p \leq 0.05)$ through the Bootstrapping analysis using 300 iterations and 5000 samples [141]. Therefore, all hypotheses were accepted. 
Table 5. Direct effects, significance, and confirmation of hypotheses.

\begin{tabular}{cccccc}
\hline Hypothesis & Relationship & Path Coefficient $(\boldsymbol{\beta})$ & $\boldsymbol{t}$-Value & $\boldsymbol{p}$ & Supp. \\
\hline H1 & ECU $\rightarrow$ EIA & 0.210 & 3.330 & 0.030 & YES \\
H2 & ECU $\rightarrow$ BIN & 0.756 & 14.375 & 0.000 & YES \\
H3 & BIN $\rightarrow$ GPP & 0.843 & 25.894 & 0.000 & YES \\
H4 & GPP $\rightarrow$ PER & 0.336 & 3.445 & 0.041 & YES \\
H5 & PER $\rightarrow$ SUN & 0.340 & 4.103 & 0.032 & YES \\
H6 & SUN $\rightarrow$ PVA & 0.533 & 5.060 & 0.000 & YES \\
H7 & PVA $\rightarrow$ SEF & 0.529 & 4.639 & 0.000 & YES \\
H8 & SEF $\rightarrow$ EIA & 0.680 & 12.036 & 0.000 & YES \\
\hline
\end{tabular}

Therefore, we first confirm the direct influence of culture and education on perceptions of entrepreneurial structures and infrastructures (H1) and on entrepreneurial intention and behaviour (H2). This relationship had already been tested in the literature [45,87]. For example, Pérez-Suárez and Sánchez-Torné [148] have corroborated the impact of education on entrepreneurial intention, particularly in the case of economics degree students. It was also found that, as some authors claim, government policies and programmes that foster entrepreneurship at the regional level depend on perceptions and demands regarding the degree of the adequacy of the existing infrastructures in the region (H3) [149]. As Martínez-Fierro, Biedma-Ferrer, and Ruiz-Navarro [91] propose through information about 62 countries, the perceived economic development has a more significant impact on government programmes and R\&D. The confirmation of hypothesis 4 (H4) entails demonstrating that perception of government policies and programmes are related to entrepreneurship influence, entrepreneurship opportunity and the ease of undertaking entrepreneurship [80]. In particular, Wu, Yuan and Pan [101] showed that teachers in Higher Education could influence the development of such perceptions using information and communication technologies. As suggested in the literature, hypothesis 5 (H5) is confirmed, as it is found that the perception of how contextual factors facilitate entrepreneurship directly or indirectly influences the formation of the subjective norm [30]. For example, Legros and Cislaghi [110] suggest that the shared perception about legal norms influences the subjective norm. In turn, the influence of subjective norms on values confirms hypothesis 6 (H6). For example, Sihombing [150] found a relationship in Indonesian microenterprise creation, and Choongo, Paas, Masurel, Van Burg, and Lungu found it in Zambia [151]. The impact of personal values on self-efficacy has also been proved (H7). Li, Bilimoria, Wang and Guo [135] demonstrated this relationship in a comparative study in China regarding the values associated with the male and female gender. Finally, entrepreneurial self-efficacy is shown to be the best predictor of entrepreneurial intention and start-up behaviour, as Asimakopoulos, Hernández and Miguel [131], and Hussain, Nazir, Hashmi, Shaheen, Akram, Waseem and Arshad [132] have confirmed.

\subsubsection{Analysis of the Predictive Potential of the Causal Proposed Model}

In order to analyse the predictive potential of the causal model proposed in this study, a series of indicators were calculated. The $\mathrm{R}^{2}$ indicator (coefficient of determination) was calculated, and the value of the dependent construct (EIA) was 0.546, higher than 0.500 [144] (Table 3). In addition, the indicator $Q^{2}$ was calculated in a redundancy-based prediction way through the blindfolding process $(\mathrm{k}=10)$. The result showed that all values were above zero $\left(\mathrm{Q}^{2}>0\right)$ in items and latent variables, being within the interval $(0.10,0.25)[141]$ (Table 3). In addition, through the PLSPredict technique, it was confirmed that $80 \%$ of the observed variables produced lower prediction errors using root mean square residual (RMSR) compared to the LM outcomes [144]. Finally, the finite mixture observed revealed that the results were not distorted by unobserved heterogeneity [144].

Considering the above concerning objective 2 of this study, the results show that the proposed causal model is internally valid, reliable, and structurally adequate. By confirming all the hypotheses of the model, the causal relationships that have been proposed in the literature by other authors and that have served as a basis for the formulation of the 
hypotheses in this study werew demonstrated. This also confirms the theoretical foundation of the proposed model using GEM country data and variables. Likewise, the proposed causal model confirms that contextual variables influence entrepreneurial intention and action through personal variables [5,30]. Finally, in confirming the predictive potential of GEM data using PLS-SEM, the suggestions of other authors were addressed [34,152].

\subsection{Results Related to Objective 3: Identify the GEM Priority Variables for Predicting} Entrepreneurial Intention and Action

To achieve objective 3, an Importance-Performance Matrix Analysis (IPMA) was conducted. This is a method introduced by Martilla and James in 1977, which has been used in several sectors, such as tourism, although to a lesser extent in the context of entrepreneurship $[108,143,153]$ (Figure 2). IPMA aims to compare the importance of antecedent constructs (according to total effects) in the configuration of a given construct (according to their average scores) [154-156]. IPMA allows researchers and practitioners to prioritise the management of specific independent constructs to improve the outcomes of the target construct, with greater efficiency in the use of resources $[157,158]$. This study shows that, in the proposed causal model, there are no constructs that have high importance and low performance. The most relevant construct to achieve entrepreneurial intention and action is SEF (Self-efficacy), as it has high importance and its performance is above average. It is followed in importance by the constructs of PVA (Personal Values), SUN (Subjective Norm) and ECU (Education and Culture). Finally, the least relevant constructs for achieving entrepreneurial intention and action are BIN (Basic Infrastructures), GPP (Government Policies and Programmes) and PER (Perceptions), which would require the least effort and resources. It confirms the importance given in the literature to self-efficacy in predicting entrepreneurial behaviour [132], followed by other personal variables, such as values and subjective norms [151].

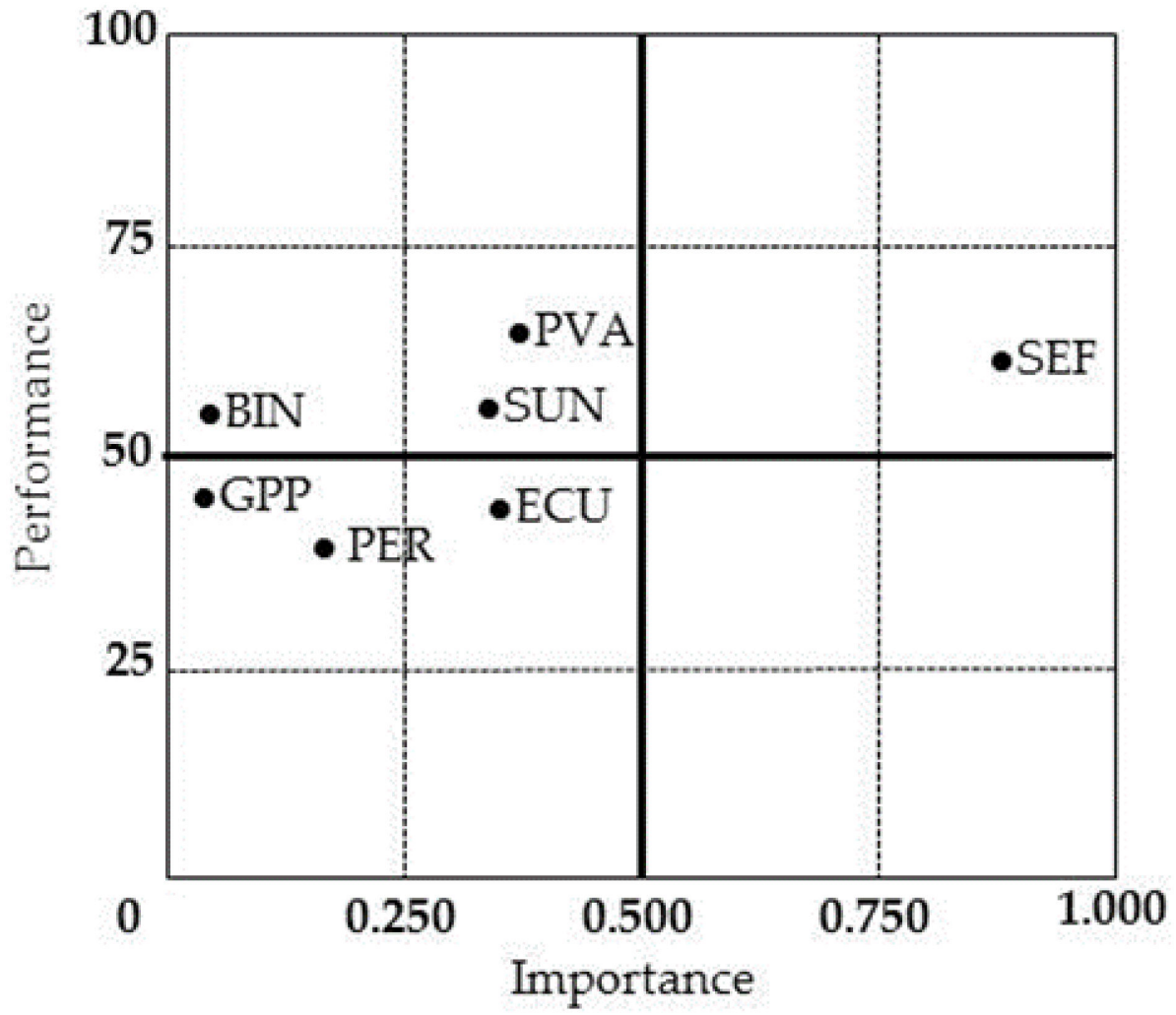

Figure 2. Importance-Performance Analysis (IPMA). Source: Authors. 
5.5. Results Related to Objective 4: To Determine Whether There Are Significant Differences in Causal Relationships between Countries with High and Low TEA

Finally, to achieve objective 4 of this study, a PLS-MGA multigroup analysis was carried out, considering that it is especially useful for research in the global comparative context of countries [155]. Before conducting the multigroup analysis, the country sample was divided into two groups, the first group with higher TEA and the second group with a lower TEA level. Each group included $50 \%$ of the total sample. The invariance of the measure was then tested using the Measurement Invariance of Composite Models (MICOM) procedure [159,160] (Table 6). The first step of the MICOM procedure is to examine the invariance of the configuration. It involves checking that identical indicators have been used in both groups, equal quality treatment of the data and the same algorithm configuration $[141,159]$. Results showed that the configurational invariance (step 1) was achieved (Table 6). Confirming configurational invariance (step 1) is necessary for assessing compositional invariance (step 2) in the MICOM procedure. Compositional invariance occurs when composite scores are created equally across all groups [160]. If the original correlation is greater than or equal to the $5 \%$ quantile, then compositional invariance is established, but if the difference is smaller than the $5 \%$ quantile, then compositional invariance is not established. In this case, as shown in Table 6, compositional invariance was established.

Table 6. MICOM procedure.

\begin{tabular}{|c|c|c|c|c|c|c|c|c|c|c|c|}
\hline \multirow{3}{*}{ Const. } & Step 1 & \multirow{2}{*}{\multicolumn{2}{|c|}{$\begin{array}{c}\text { Step } 2 \\
\begin{array}{c}\text { Compositional } \\
\text { Invariance }\end{array}\end{array}$}} & \multirow{3}{*}{$\begin{array}{l}\text { Partial } \\
\text { Measurement } \\
\text { Invariance } \\
\text { Established }\end{array}$} & \multirow{2}{*}{\multicolumn{3}{|c|}{$\frac{\text { Step 3a }}{\text { Equal Mean Assessment }}$}} & \multirow{2}{*}{\multicolumn{3}{|c|}{$\begin{array}{c}\text { Step } 3 b \\
\text { Equal Variance } \\
\text { Assessment }\end{array}$}} & \multirow{3}{*}{$\begin{array}{c}\text { Full } \\
\text { Measurement } \\
\text { Invariance } \\
\text { Established }\end{array}$} \\
\hline & \multirow{2}{*}{$\begin{array}{c}\text { Configuration } \\
\text { Invariance }\end{array}$} & & & & & & & & & & \\
\hline & & $\begin{array}{c}\text { Original } \\
\text { Correlation }\end{array}$ & $5.00 \%$ & & Dif. & $\begin{array}{l}\text { Confid. } \\
\text { Interval }\end{array}$ & Equal & Dif. & $\begin{array}{l}\text { Confid. } \\
\text { Interval }\end{array}$ & Equal & \\
\hline ECU & Yes & 0.994 & 0.991 & Yes & 0.018 & $\begin{array}{l}(-0.530, \\
0.486)\end{array}$ & Yes & -0.003 & $\begin{array}{l}(-0.694 \\
0.668)\end{array}$ & Yes & Yes \\
\hline BIN & Yes & 1.000 & 0.998 & Yes & 0.631 & $\begin{array}{l}(-0.559 \\
0.555)\end{array}$ & No & -0.327 & $\begin{array}{l}(-0.823 \\
0.788)\end{array}$ & Yes & No \\
\hline GPP & Yes & 1.000 & 0.999 & Yes & 0.372 & $\begin{array}{l}(-0.573, \\
0.506)\end{array}$ & Yes & 0.079 & $\begin{array}{l}(-0.672 \\
0.582)\end{array}$ & Yes & Yes \\
\hline PER & Yes & 0.958 & 0.396 & Yes & 0.042 & $\begin{array}{l}(-0.527 \\
0.555)\end{array}$ & Yes & 0.527 & $\begin{array}{l}(-0.823 \\
0.802)\end{array}$ & Yes & Yes \\
\hline SUN & Yes & 0.955 & 0.856 & Yes & -0.843 & $\begin{array}{l}(-0.590 \\
0.575)\end{array}$ & No & 0.136 & $\begin{array}{l}(-0.960 \\
0.876)\end{array}$ & Yes & No \\
\hline PVA & Yes & 0.994 & 0.920 & Yes & -0.292 & $\begin{array}{l}(-0574, \\
0.545)\end{array}$ & Yes & 0.307 & $\begin{array}{l}(-1.183 \\
1.162)\end{array}$ & Yes & Yes \\
\hline SEF & Yes & 0.994 & 0.994 & Yes & -0.993 & $\begin{array}{c}(-0.546 \\
0.596)\end{array}$ & No & 0.262 & $\begin{array}{c}(-0.741 \\
0.705)\end{array}$ & Yes & No \\
\hline EIA & Yes & 0.991 & 0.989 & Yes & -1.238 & $\begin{array}{l}(-0.568 \\
0.540)\end{array}$ & No & -0.707 & $\begin{array}{l}(-1.013 \\
0.921)\end{array}$ & Yes & No \\
\hline
\end{tabular}

The third step is to check the invariance of the means (step 3a) and the invariance of the variances (step $3 b$ ). Checking the invariance of means and variance involves verifying that, in both cases, their original difference lies within the interval $2.5-97.5 \%$. When the invariance of means and variances for all constructs is met, full invariance is said to exist. Otherwise, partial invariance is said to exist. Only when the existence of full invariance is confirmed can both subgroups be analysed together. When the existence of partial invariance is confirmed, a multigroup comparison can be carried out. As shown in Table 6, the existence of partial invariance is confirmed, and, therefore, the PLS-MGA multigroup analysis can be performed.

The PLS-MGA analysis was performed using two non-parametric tests: the MGA test [161] and the permutation test [162]. Both tests are considered as the most conservative PLS-SEM techniques in the PLS-SEM context [163]. Table 7 shows the path coefficients of both countries, their differences and the significance level (p) of these differences in both the AMS analysis and the permutation test. It should be noted that, concerning the 
MGA test, a hypothesis is confirmed when the $p$-value is less than 0.05 or greater than $0.95[161,164]$. In the case of the permutation test, differences are significant only when the $p$-value is less than 0.05 . According to both criteria and as shown in Table 7 , it can be stated that, although there are some differences in the causal relationships or hypotheses of the two groups of countries, these differences are not significant. Therefore, high and low TEA countries do not differ significantly in the causal relationships of the proposed model. This result does not contradict the fact that high and low TEA countries differ in some variables, as other authors have claimed [5,27], because the comparison was carried out concerning the causal relationships of the proposed model.

Table 7. Analysis of PLS-MGA multigroup.

\begin{tabular}{|c|c|c|c|c|c|c|c|}
\hline \multirow{2}{*}{ Hypothesis } & \multirow{2}{*}{ Relationship } & \multirow{2}{*}{$\begin{array}{c}\text { Path } \\
\text { Group } 1\end{array}$} & \multirow{2}{*}{$\begin{array}{c}\text { Path } \\
\text { Group } 2\end{array}$} & \multirow{2}{*}{$\begin{array}{c}\text { Path } \\
\text { Difference }\end{array}$} & \multicolumn{2}{|c|}{$p$-Value Diference } & \multirow{2}{*}{ Supported } \\
\hline & & & & & MGA Test & Permutation Test & \\
\hline H1 & $\mathrm{ECU} \rightarrow \mathrm{EIA}$ & 0.208 & 0.006 & 0.202 & 0.512 & 0.236 & $\mathrm{No} / \mathrm{No}$ \\
\hline $\mathrm{H} 2$ & $\mathrm{ECU} \rightarrow \mathrm{BIN}$ & 0.845 & 0.781 & 0.064 & 0.425 & 0.566 & $\mathrm{No} / \mathrm{No}$ \\
\hline H3 & $\mathrm{BIN} \rightarrow \mathrm{GPP}$ & 0.897 & 0.812 & 0.085 & 0.193 & 0.218 & $\mathrm{No} / \mathrm{No}$ \\
\hline $\mathrm{H} 4$ & $\mathrm{GPP} \rightarrow \mathrm{PER}$ & -0.013 & 0.501 & -0.514 & 0.096 & 0.121 & $\mathrm{No} / \mathrm{No}$ \\
\hline H5 & $\mathrm{PER} \rightarrow \mathrm{SUN}$ & 0.465 & 0.367 & 0.098 & 0.447 & 0.796 & $\mathrm{No} / \mathrm{No}$ \\
\hline H6 & $\mathrm{SUN} \rightarrow \mathrm{PVA}$ & 0.635 & 0.477 & 0.158 & 0.476 & 0.405 & $\mathrm{No} / \mathrm{No}$ \\
\hline $\mathrm{H} 7$ & $\mathrm{PVA} \rightarrow \mathrm{SEF}$ & 0.427 & 0.677 & -0.250 & 0.231 & 0.273 & $\mathrm{No} / \mathrm{No}$ \\
\hline H8 & $\mathrm{SEF} \rightarrow \mathrm{EIA}$ & 0.700 & 0.653 & 0.047 & 0.582 & 0.643 & $\mathrm{No} / \mathrm{No}$ \\
\hline
\end{tabular}

\section{Implications}

This study has responded, through its four objectives, to the concerns and demands of various authors to delve deeper into the analysis of the variables that predict the intention and action of entrepreneurship in a regional context [8,9]. This interest is because entrepreneurship at the regional level is of critical importance, as is the entrepreneur's role in creating a new venture. The results allow the following theoretical, methodological and practical implications to be drawn.

\subsection{Theoretical Implications}

The results related to the first objective confirm the theoretical foundation of the personal and contextual variables of GEM, a task that other authors had recently begun to undertake with similar results [30]. Specifically, it was found through the literature review that the number, denomination, classification and content of the personal and contextual variables of GEM have explicit parallelism with those included in the literature in this field. The theoretical foundation of GEM was also confirmed because the causal relationships (hypotheses) of the model in this study, which was fully confirmed, were based on similar relationships in the literature [20,110]. It is the case, for example, of the strong direct and positive influence of self-efficacy on entrepreneurial intention, an influence that was corroborated by the IPMA analysis (objective 3 of this study). In addition, the theoretical proposals of other authors and those of the GEM itself, i.e., that it is contextual variables that initiate the chain of quasi-salient effects that, by first influencing personal variables, culminate in entrepreneurial intention and action, are confirmed [5]. This implies that GEM reports are suitable for developing quality studies on entrepreneurial behaviour in a regional country context. Finally, the results of this study are useful to complement or confirm the theoretical findings of other authors doing work on entrepreneurial intention and action, regardless of whether or not they use GEM data.

\subsection{Methodological Implications}

The results obtained in pursuit of the second objective of this study confirm that GEM data are statistically significant and adequate for the development of valid and reliable causal models to predict intention and the action of starting up a new company at the country level. They are in line with recent findings by other authors who have 
confirmed the high validity and reliability of GEM data using the Rasch mathematical model [30]. GEM reports used SEM methodology in some predictive studies, but these studies only considered a small number of variables and countries. On the other hand, the results associated with objectives 2, 3 and 4 of this study confirm that the PLS-SEM methodology is particularly suitable for developing predictive models of entrepreneurial intention and action using all the variables and countries in GEM reports. It is partly because models generated using PLS-SEM methodology are stable when using small samples and many variables.

\subsection{Practical Implications}

The causal model proposed in this study (objective 2) is of practical use to researchers and practitioners who wish to predict entrepreneurial behaviour at the country level, following other authors' suggestions. First, the proposed model is realistic because it includes many contextual and personal variables, consistent with the complex nature of start-up behaviour $[20,26]$. Second, the model predicts entrepreneurial intention, as is common in the literature, and the action of creating a business (through the TEA). It is one of the novelties of this study [28,29]. In addition, it is noteworthy that, through the pursuit of objective 3 (IPMA analysis), entrepreneurship practitioners and institutions have valuable information about which variables are critical in shaping entrepreneurial behaviour at the country level (e.g., self-efficacy) [165-168]. These variables should be allocated to and actions implemented as a matter of priority. Finally, it is worth noting that, although no significantly different causal relationships between high and low TEA countries were identified through PLS-MGA analysis, they are more significant in the case of high TEA countries, except the relationships associated with $\mathrm{H} 4$ (GPP $\rightarrow$ PER) and H7 $(\mathrm{PVA} \rightarrow \mathrm{SEF})$.

\section{Conclusions}

Through its four objectives, this study responded to the concerns and demands of various authors to delve deeper into the analysis of the variables that predict the intention and action of entrepreneurship in a regional context [8,9]. This interest is because entrepreneurship at the regional level is critically important, as is the entrepreneur's role in creating a new venture. The results allowed the following theoretical, methodological and practical implications to be drawn.

First, it is necessary for researchers and practitioners in entrepreneurship at the regional level to have regular access to comprehensive and quality data to carry out their studies. However, the data and reports on regional entrepreneurship from institutions, such as GEM, must have a sufficient theoretical basis, validity, and reliability. It is critical because these type of data are increasingly used in entrepreneurship research and promotion. Thus, studies will be better able to compare, enrich and complement theoretical knowledge in the field in a two-way street.

Second, the methodologies used to predict entrepreneurial behaviour successfully (e.g., PLS-SEM) must be used to design valid and reliable models, and their predictive potential in this field must be sufficiently tested. Moreover, such methodology should be open and flexible to include numerous variables and relationships beyond those traditionally considered. In addition, such a methodology should include internal processes to identify predictor variables in which to prioritise policies, actions, and resources and differentiate groups of countries according to some criteria of interest (e.g., countries with high and low TEA).

Third, the causal relationships (hypotheses) included in such models should be based on sufficiently well-tested scientific studies and include a broad set of contextual and personal variables to reflect the complex nature of entrepreneurial behaviour better. Additionally, the causal models that are developed must include, as a dependent construct, other variables that, in addition to intention, reflect the actual behaviour of starting up a business (e.g., TEA). 
It is concluded that the personal and contextual variables of the GEM have sufficient theoretical foundations. It implies that GEM reports are suitable for developing quality studies on entrepreneurial behaviour in a regional country context. At the methodological level, it is concluded that GEM data are statistically significant and adequate for developing valid and reliable causal models to predict intention and the action of starting up a new company at the country level. In addition, at a practical level, it is concluded that the causal model proposed in this study is realistic and of practical use to researchers and practitioners who wish to predict entrepreneurial behaviour at the country level. Through the IPMA analysis, entrepreneurship practitioners and institutions have valuable information about which variables are critical in shaping entrepreneurial behaviour (e.g., self-efficacy).

Despite the useful implications and conclusions of this study, it is not without its limitations. Firstly, GEM only provides information for a limited number of countries. Secondly, the global GEM reports are not predictive, and they do not establish a causal relationship between entrepreneurship variables and entrepreneurial behaviour. A future research line could predict entrepreneurial behaviour through GEM data by identifying some criteria to distinguish casual relationships between high and low entrepreneurial countries. Additionally, it would be interesting to carry out the same study when there is no longer a COVID-19 pandemic to carry out comparisons.

Author Contributions: Conceptualization, J.A.M.-G., C.D.Á.-A., J.M.-J. and U.K.; methodology, J.A.M.-G., C.D.Á.-A. and U.K.; software, J.A.M.-G., C.D.Á.-A. and J.M.-J.; validation, J.A.M.-G., C.D.Á.-A., J.M.-J. and U.K.; formal analysis, J.A.M.-G., C.D.Á.-A., J.M.-J. and U.K.; investigation, J.A.M.-G., C.D.Á.-A., J.M.-J. and U.K.; data curation, J.A.M.-G., C.D.Á.-A., J.M.-J. and U.K.; writingoriginal, U.K.; writing-review and editing, J.A.M.-G., C.D.Á.-A., J.M.-J. and U.K.; supervision, J.A.M.-G., C.D.Á.-A., J.M.-J. and U.K. All authors have read and agreed to the published version of the manuscript.

Funding: This research received no external funding.

Institutional Review Board Statement: Not applicable.

Informed Consent Statement: Not applicable.

Data Availability Statement: Not applicable.

Conflicts of Interest: The authors declare no conflict of interest.

\section{Appendix A}

Results of Factor Analysis. This appendix presents the results of the Factor Analysis that was carried out using the principal components extraction method and the Varimax rotation with Kaiser normalization [20]. A structure of eight Factors (latent variables) was obtained with adequate significance $(p \leq 0.05)$ (Table A1). The sum of the squared loads of the rotation explained $87.28 \%$ of the variance accumulated through the eight resulting factors.

Table A1. Results of the Factor Analysis.

\begin{tabular}{|c|c|c|c|c|c|c|c|c|}
\hline Constructs and Observed Variables & ECU & BIN & GPP & PER & SUN & PVA & SEF & EIA \\
\hline (a) Contextual Variables & & & & & & & & \\
\hline CES: Entrepreneurial Education at the School Stage & 0.716 & & & & & & & \\
\hline CPE: Entrepreneurial Education at the Post-School Stage & 0.651 & & & & & & & \\
\hline CSN: Cultural and Social Norms & 0.672 & & & & & & & \\
\hline CEF: Entrepreneurial Finance & & 0.750 & & & & & & \\
\hline CLI: Commercial and Legal Infrastructure & & 0.656 & & & & & & \\
\hline CMO: Internal Market Openness & & 0.824 & & & & & & \\
\hline CPI: Physical Infrastructure & & 0.631 & & & & & & \\
\hline CGP: Government Entrepreneurship Programmes & & & 0.922 & & & & & \\
\hline
\end{tabular}


Table A1. Cont.

\begin{tabular}{|c|c|c|c|c|c|c|c|c|}
\hline Constructs and Observed Variables & ECU & BIN & GPP & PER & SUN & PVA & SEF & EIA \\
\hline CRD: R\&D Transfer & & & 0.890 & & & & & \\
\hline CSR: Governmental Policies: Support and Relevance & & & 0.932 & & & & & \\
\hline CTB: Government Policies: Taxes and Bureaucracy & & & 0.830 & & & & & \\
\hline (b) Personal Variables & & & & & & & & \\
\hline PES Ease of Starting a Business & & & & 0.908 & & & & \\
\hline PPO Perceived Opportunities & & & & 0.776 & & & & \\
\hline PIC Innovativy Capacity & & & & & 0.853 & & & \\
\hline PKS Knowing a Startup Entrepreneur & & & & & 0.912 & & & \\
\hline PCC Entrepreneurship as a Good Career Choice & & & & & & 0.721 & & \\
\hline PHS High Status to Successful Entrepreneurs & & & & & & 0.866 & & \\
\hline PPC Perceived Capabilities & & & & & & & 0.812 & \\
\hline PVI Vision & & & & & & & 0.893 & \\
\hline PEI Entrepreneurial Intention & & & & & & & & 0.844 \\
\hline TEA Total Early stage Entrepreneurial Activity & & & & & & & & 0.681 \\
\hline
\end{tabular}

\section{References}

1. Clausen, T.H. Entrepreneurial thinking and action in opportunity development: A conceptual process model. Int. Small Bus. J. 2020, 38, 21-40. [CrossRef]

2. Michaelis, T.L.; Carr, J.C.; Scheaf, D.J.; Pollack, J.M. The frugal entrepreneur: A self-regulatory perspective of resourceful entrepreneurial behavior. J. Bus. Ventur. 2000, 35, 105969. [CrossRef]

3. Baciu, E.L.; Vîrga, D.; Lazăr, T.A. What characteristics help entrepreneurs 'make it' early on in their entrepreneurial careers? Findings of a regional study from Romania. Sustainability 2020, 12, 5028. [CrossRef]

4. Zulfiqar, S.; Al-Reshidi, H.A.; Al Moteri, M.A.; Feroz, H.M.B.; Yahya, N.; Al-Rahmi, W.M. Understanding and predicting students' entrepreneurial intention through business simulation games: A perspective of COVID-19. Sustainability 2021, 13, 1838. [CrossRef]

5. Bosna, N.; Hill, S.; Ionescu-Somers, A.; Kelley, D.; Guerrero, M.; Schott, T. Global Entrepreneurship Monitor (GEM)—2020/2021 Global Report; Global Entrepreneurship Research Association, London Business School: London, UK, 2021.

6. Anand, A.; Argade, P.; Barkemeyer, R.; Salignac, F. Trends and patterns in sustainable entrepreneurship research: A bibliometric review and research agenda. J. Bus. Ventur. 2021, 36, 106092. [CrossRef]

7. Furdui, A.; Lupu-Dima, L.; Edelhauser, E. Implications of entrepreneurial intentions of Romanian secondary education students, over the Romanian business market development. Processes 2021, 9, 665. [CrossRef]

8. Doh, S. Social entrepreneurship and regional economic development: The case of social enterprise in South Korea. Sustainability 2020, 12, 8843. [CrossRef]

9. Novejarque Civera, J.; Pisá Bó, M.; López-Muñoz, J.F. Do contextual factors influence entrepreneurship? Spain's regional evidences. Int. Entrep. Manag. J. 2021, 17, 105-129. [CrossRef]

10. Ruzzier, M.; Douglas, E.J.; Ruzzier, M.K.; Hojnik, J. International entrepreneurial orientation and the intention to internationalize. Sustainability 2020, 12, 5647. [CrossRef]

11. Xie, Z.; Wang, X.; Xie, L.; Duan, K. Entrepreneurial ecosystem and the quality and quantity of regional entrepreneurship: A configurational approach. J. Bus. Res. 2021, 128, 499-509. [CrossRef]

12. Carayannis, E.; Jones, P.; Liargovas, P.; Apostolopoulos, N. Entrepreneurship and the European Union policies after 60 years of common European vision: Regional and spatial perspectives. J. Small Bus. Entrep. 2020, 32, 517-522. [CrossRef]

13. Bernhard, I.; Olsson, A.K. Network collaboration for local and regional development. The case of Swedish women entrepreneurs. Int. J. Entrep. Small Bus. 2020, 41, 539-561. [CrossRef]

14. Niu, Z.; Zhou, X.; Pei, H. Effect of perceived status of entrepreneur on firm's CSR behavior: Evidence from Chinese private enterprises survey. Financ. Res. Lett. 2021, 39, 101561. [CrossRef]

15. Del Monte, A.; Pennacchio, L. Historical roots of regional entrepreneurship: The role of knowledge and creativity. Small Bus. Econ. 2020, 55, 1-22. [CrossRef]

16. Hagebakken, G.; Reimers, C.; Solstad, E. Entrepreneurship education as a strategy to build regional sustainability. Sustainability 2021, 13, 2529. [CrossRef]

17. Abdullah, N.; Hadi, N.U.; Dana, L.P. The nexus between entrepreneur skills and successful business: A decompositional analysis. Int. J. Entrep. Small Bus. 2018, 34, 249-265. [CrossRef]

18. Obschonka, M.; Zhou, M.; Zhou, Y.; Zhang, J.; Silbereisen, R.K. “Confucian” traits, entrepreneurial personality, and entrepreneurship in China: A regional analysis. Small Bus. Econ. 2019, 53, 961-979. [CrossRef]

19. Del Bosco, B.; Mazzucchelli, A.; Chierici, R.; Di Gregorio, A. Innovative startup creation: The effect of local factors and demographic characteristics of entrepreneurs. Int. Entrep. Manag. J. 2021, 17, 145-164. [CrossRef]

20. Martínez-González, J.A.; Kobylinska, U.; García-Rodríguez, F.J.; Nazarko, L. Antecedents of entrepreneurial intention among young people: Model and regional evidence. Sustainability 2019, 11, 6993. [CrossRef] 
21. Litzky, B.; Winkel, D.; Hance, J.; Howell, R. Entrepreneurial intentions: Personal and cultural variations. J. Small Bus. Entrep. 2020, 27, 1029-1047. [CrossRef]

22. Nakara, W.A.; Laouiti, R.; Chavez, R.; Gharbi, S. An economic view of entrepreneurial intention. Int. J. Entrep. Behav. Res. 2020, 26, 1807-1826. [CrossRef]

23. Elston, J.A.; Weidinger, A. Entrepreneurial intention and regional internationalization in China. Small Bus. Econ. 2019, 53, 1001-1015. [CrossRef]

24. Ruiz-Alba, J.L.; Guzman-Parra, V.F.; Vila-Oblitas, J.R.; Morales-Mediano, J. Entrepreneurial intentions: A bibliometric analysis J. Small Bus. Entrep. 2021, 28, 121-133. [CrossRef]

25. Renko, M.; Bullough, A.; Saeed, S. How do resilience and self-efficacy relate to entrepreneurial intentions in countries with varying degrees of fragility? A six-country study. Int. Small Bus. J. 2021, 39, 130-156. [CrossRef]

26. Hien, D.T.T.; Cho, S.E. The effect of software developers' capabilities on entrepreneurial intention in ICT industries. Int. J. Entrep. 2018, 22, 1-17.

27. Arabiun, A.; Mobini-Dehkordi, A.; Salajegheh, N. Conceptualization of "entrepreneurial action". J. Entrep. Dev. 2019, 12, 241-260. [CrossRef]

28. Herrington, M.; Coduras, A. The national entrepreneurship framework conditions in sub-Saharan Africa: A comparative study of GEM data/National Expert Surveys for South Africa, Angola, Mozambique and Madagascar. J. Glob. Entrep. Res. 2019, 9 , 1-24. [CrossRef]

29. Ali, J.; Jabeen, Z. Understanding entrepreneurial behavior for predicting start-up intention in India: Evidence from global entrepreneurship monitor (GEM) data. J. Public Aff. 2020, 22, e2399. [CrossRef]

30. Martínez-González, J.A.; Kobylinska, U.; Gutiérrez-Taño, D. Exploring personal and contextual variables of the global entrepreneurship monitor through the Rasch Mathematical Model. Mathematics 2021, 9, 1838. [CrossRef]

31. Roomi, M.A.; Saiz-Alvarez, J.M.; Coduras, A. Measuring sustainable entrepreneurship and eco-innovation: A methodological proposal for the Global Entrepreneurship Monitor (GEM). Sustainability 2021, 13, 4056. [CrossRef]

32. Hechavarría, D.M.; Ingram, A.E. Entrepreneurial ecosystem conditions and gendered national-level entrepreneurial activity: A 14-year panel study of GEM. Small Bus. Econ. 2019, 53, 431-458. [CrossRef]

33. Voda, A.I.; Butnaru, G.I.; Butnaru, R.C. Enablers of entrepreneurial activity across the european union-an analysis using GEM individual data. Sustainability 2020, 12, 1022. [CrossRef]

34. Yoon, H.D.; Kim, N.; Buisson, B.; Phillips, F. A cross-national study of knowledge, government intervention, and innovative nascent entrepreneurship. J. Bus. Res. 2018, 84, 243-252. [CrossRef]

35. Bergmann, H.; Mueller, S.; Schrettle, T. The use of global entrepreneurship monitor data in academic research: A critical inventory and future potentials. Int. J. Entrep. Ventur. 2014, 6, 242-276. [CrossRef]

36. Álvarez, C.; Urbano, D.; Amorós, J.E. GEM research: Achievements and challenges. Small Bus. Econ. 2014, 42, 445-465. [CrossRef]

37. Simón-Moya, V.; Revuelto-Taboada, L.; Guerrero, R.F. Institutional and economic drivers of entrepreneurship: An international perspective. J. Bus. Res. 2014, 67, 715-721. [CrossRef]

38. Ahadi, S.; Kasraie, S. Contextual factors of entrepreneurship intention in manufacturing SMEs: The case study of Iran. J. Small Bus. Enterp. Dev. 2020, 27, 633-657. [CrossRef]

39. Matos, S.; Hall, J. An exploratory study of entrepreneurs in impoverished communities: When institutional factors and individual characteristics result in non-productive entrepreneurship. Entrep. Reg. Dev. 2019, 32, 134-155. [CrossRef]

40. Pérez-Macía, N.; Fernández-Fernández, J.L. Personal and contextual factors influencing the entrepreneurial intentions of people with disabilities in Spain. Disabil. Soc. 2021. [CrossRef]

41. Touzani, M.; Jlassi, F.; Maalaoui, A.; Hassine, R.B.H. Contextual and cultural determinants of entrepreneurship in pre- and post-revolutionary Tunisia. J. Small Bus. Enterp. Dev. 2015, 22, 160-179. [CrossRef]

42. Cherrier, H.; Goswami, P.; Ray, S. Social entrepreneurship: Creating value in the context of institutional complexity. J. Bus. Res. 2018, 86, 245-258. [CrossRef]

43. Tsordia, C.; Papadimitriou, D. The Role of Theory of Planned Behavior on Entrepreneurial Intention of Greek Business Students. Int. J. Synerg. Res. 2015, 4, 23-37. [CrossRef]

44. Bergmann, H.; Hundt, C.; Sternberg, R. What makes student entrepreneurs? On the relevance (and irrelevance) of the university and the regional context for student start-ups. Small Bus. Econ. 2016, 47, 53-76. [CrossRef]

45. Liñán, F.; Fernandez-Serrano, J. National culture, entrepreneurship and economic development: Different patterns across the European Union. Small Bus. Econ. 2014, 42, 685-701. [CrossRef]

46. Audretsch, D.B.; Obschonka, M.; Gosling, S.D.; Potter, J. A new perspective on entrepreneurial regions: Linking cultural identity with latent and manifest entrepreneurship. Small Bus. Econ. 2016, 48, 681-697. [CrossRef]

47. Canestrino, R.; Cwiklicki, M.; Magliocca, P.; Pawełek, B. Understanding social entrepreneurship: A cultural perspective in business research. J. Bus. Res. 2020, 110, 132-143. [CrossRef]

48. Liñán, F.; Fernández, J.; Romero, I. Necessity and opportunity entrepreneurship: The mediating effect of culture. Rev. Econ. Mund. 2013, 33, 21-47.

49. Martínez-Rodriguez, I.; Callejas-Albiñana, F.E.; Callejas-Albiñana, A.I. Economic and socio-cultural drivers of necessity and opportunity entrepreneurship depending on the business cycle phase. J. Bus. Econ. Manag. 2020, 21, 373-394. [CrossRef] 
50. Chien-Chi, C.; Sun, B.; Yang, H.; Zheng, M.; Li, B. Emotional competence, entrepreneurial self-efficacy, and entrepreneurial intention: A study based on China college students' social entrepreneurship project. Front. Psychol. 2020, 11, 547627. [CrossRef]

51. Yan, X.; Gu, D.; Liang, C.; Zhao, S.; Lu, W. Fostering sustainable entrepreneurs: Evidence from China college students' "Internet Plus" innovation and entrepreneurship competition (CSIPC). Sustainability 2018, 10, 3335. [CrossRef]

52. Esfandiar, K.; Sharifi-Tehrani, M.; Pratt, S.; Altinay, L. Understanding entrepreneurial intentions: A developed integrated structural model approach. J. Bus. Res. 2019, 94, 172-182. [CrossRef]

53. Ohanu, I.B.; Shodipe, T.O. Influence of the link between resources and behavioural factors on the entrepreneurial intentions of electrical installation and maintenance work students. J. Innov. Entrep. 2021, 10, 13. [CrossRef]

54. Bae, T.; Qian, S.; Miao, C.; Fiet, J. The relationship between entrepreneurship education and entrepreneurial intentions: A meta-analytic review. Entrep. Theory Pract. 2014, 38, 217-254. [CrossRef]

55. Moriano, J.A.; Gorgievski, M.; Laguna, M.; Stephan, U.; Zarafshani, K. A cross-cultural approach to understanding entrepreneurial intention. J. Career Dev. 2011, 39, 162-185. [CrossRef]

56. Shapero, A.; Sokol, L. The social dimensions of entrepreneurship. In Encylopedia of Entrepreneurship; Kent, C., Sexton, L., Vesper, K., Eds.; Prentice Hall: Englewood Cliffs, NJ, USA, 1982; pp. 72-90.

57. Ajzen, I. The theory of planned behavior. Organ. Behav. Hum. Dec. 1991, 50, 179-211. [CrossRef]

58. Schlaegel, C.; Koenig, M. Determinants of entrepreneurial intent: A meta-analytic test and integration of competing models. Entrep. Theory Pract. 2014, 38, 291-332. [CrossRef]

59. Krueger, N.F.; Reilly, M.D.; Carsrud, A.L. Competing models of entrepreneurial intentions. J. Bus. Ventur. 2000, 15, 411-432. [CrossRef]

60. Mikić, M.; Horvatinović, T.; Turčić, I. A closer look at entrepreneurial intentions. Econ. Bus. Lett. 2020, 9, 361-369. [CrossRef]

61. Fitzsimmons, J.R.; Douglas, E.J. Interaction between feasibility and desirability in the formation of entrepreneurial intentions. J. Bus. Ventur. 2011, 26, 431-440. [CrossRef]

62. Vuorio, A.M.; Puumalainen, K.; Fellnhofer, K. Drivers of entrepreneurial intentions in sustainable entrepreneurship. Int. J. Entrep. Behav. Res. 2018, 24, 359-381. [CrossRef]

63. Vamvaka, V.; Stoforos, C.; Palaskas, T.; Botsaris, C. Attitude toward entrepreneurship, perceived behavioral control, and entrepreneurial intention: Dimensionality, structural relationships, and gender differences. J. Innov. Entrep. 2020, 9, 5. [CrossRef]

64. Van Gelderen, M.; Kautonen, T.; Wincent, J.; Biniari, M. Implementation intentions in the entrepreneurial process: Concept, empirical findings, and research agenda. Small Bus. Econ. 2017, 51, 923-941. [CrossRef]

65. Ciuchta, M.P.; Finch, D. The mediating role of self-efficacy on entrepreneurial intentions: Exploring boundary conditions. J. Bus. Ventur. Insights 2019, 11, e00128. [CrossRef]

66. Powers, B.; Le Loarne-Lemaire, S.; Maalaoui, A.; Kraus, S. "When I get older, I wanna be an entrepreneur": The impact of disability and dyslexia on entrepreneurial self-efficacy perception. Int. J. Entrep. Behav. Res. 2021, 27, 434-451. [CrossRef]

67. Cardella, G.M.; Hernández-Sánchez, B.R.; García, J.C.S. Entrepreneurship and family role: A systematic review of a growing research. Front. Psychol. 2020, 10, 2939. [CrossRef]

68. Georgescu, M.A.; Herman, E. The impact of the family background on students' entrepreneurial intentions: An empirical analysis. Sustainability 2020, 12, 4775. [CrossRef]

69. Sedeh, A.; Abootorabi, H.; Zhang, J. National social capital, perceived entrepreneurial ability and entrepreneurial intentions. Int. J. Entrep. Behav. Res. 2021, 27, 334-355. [CrossRef]

70. Ndofirepi, T.M. How spatial contexts, institutions and self-identity affect entrepreneurial intentions. J. Entrep. Emerg. Econ. 2021, 13, 153-174. [CrossRef]

71. González-Serrano, M.H.; González-García, R.J.; Carvalho, M.J.; Calabuig, F. Predicting entrepreneurial intentions of sports sciences students: A cross-cultural approach. J. Hosp. Leis. Sports Tour. Educ. 2021, 29, 100322. [CrossRef]

72. Halberstadt, J.; Schank, C.; Euler, M.; Harms, R. Learning sustainability entrepreneurship by doing: Providing a lecturer-oriented service learning framework. Sustainability 2019, 11, 1217. [CrossRef]

73. Doanh, D.C. The role of contextual factors on predicting entrepreneurial intention among Vietnamese students. Entrep. Bus. Econ. Rev. 2021, 9, 169-188. [CrossRef]

74. Duong, C.D.; Nguyen, H.X.; Ngo, T.V.N.; Nguyen, V.H.; Nguyen, T.P.L. The impact of individual and environmental characteristics on students' entrepreneurial intention. Manag. Sci. Lett. 2020, 10, 599-608. [CrossRef]

75. Moussa, N.B.; Kerkeni, S. The role of family environment in developing the entrepreneurial intention of young Tunisian students. Entrep. Bus. Econ. Rev. 2021, 9, 31-45. [CrossRef]

76. Yu, T.; Khalid, N.; Ahmed, U. Factors influencing entrepreneurial intention among foreigners in Kazakhstan. Sustainability 2021, 13, 7066. [CrossRef]

77. Ramos-Rodríguez, A.R.; Medina-Garrido, J.A.; Lorenzo-Gómez, J.D.; Ruiz-Navarro, J. What you know or who you know? The role of intellectual and social capital in opportunity recognition. Int. Small Bus. J. 2010, 28, 566-582. [CrossRef]

78. Dileo, I.; García-Pereiro, T. Assessing the impact of individual and context factors on the entrepreneurial process. A cross-country multilevel approach. Int. Entrep. Manag. J. 2019, 15, 1393-1441. [CrossRef]

79. Castaño, M.S.; Méndez, M.T.; Galindo, M.Á. The effect of public policies on entrepreneurial activity and economic growth. J. Bus. Res. 2016, 69, 5280-5285. [CrossRef] 
80. Zhao, Q.J.; Zhou, B.F.; Linm, J.H. Influence of environmental perception on college students' entrepreneurial intention and gender differences. J. Hum. Agric. Univ. 2019, 1, 89-96. [CrossRef]

81. Hofstede, G. The GLOBE debate: Back to relevance. J. Int. Bus. Stud. 2010, 41, 1339-1346. [CrossRef]

82. Dheer, R.J.S. Cross-national differences in entrepreneurial Activity: Role of culture and institutional factors. Small Bus. Econ. 2017, 48, 813-842. [CrossRef]

83. Fernández-Serrano, J.; Berbegal, V.; Velasco, F.; Expósito, A. Efficient entrepreneurial culture: A cross-country analysis of developed countries. Int. Entrep. Manag. J. 2018, 14, 105-127. [CrossRef]

84. Çelikkol, M.; Kitapçi, H.; Döven, G. Culture's impact on entrepreneurship \& interaction effect of economic development level: An 81 country study. J. Bus. Econ. Manag. 2019, 20, 777-797. [CrossRef]

85. Haddad, G.; Esposito, M.; Tse, T. The social cluster of gender, agency and entrepreneurship. Int. J. Entrep. Small Bus. 2016, 28, 431-450. [CrossRef]

86. Boldureanu, G.; Ionescu, A.M.; Bercu, A.M.; Bedrule-Grigorut, M.V.; Boldureanu, D. Entrepreneurship education through successful entrepreneurial models in higher education Institutions. Sustainability 2020, 12, 1267. [CrossRef]

87. Fayolle, A.; Gailly, B. The impact of entrepreneurship education on entrepreneurial attitudes and intention: Hysteresis and persistence. J. Small Bus. Manag. 2015, 53, 75-93. [CrossRef]

88. Wu, F.; Mao, C. Business environment and entrepreneurial motivations of urban students. Front. Psychol. 2020, 11, 1483. [CrossRef]

89. Robson, P.J.A.; Wijbenga, F.; Parker, S. Entrepreneurship and policy. Challenges and directions for future research. Int. Small Bus. J. 2009, 27, 531-535. [CrossRef]

90. Spyridaki, N.A.; Ioannou, A.; Flamos, A. How can the context affect policy decision-making: The case of climate change mitigation policies in the Greek building sector. Energies 2016, 9, 294. [CrossRef]

91. Martínez-Fierro, S.; Biedma-Ferrer, J.M.; Ruiz-Navarro, J. Impact of high-growth start-ups on entrepreneurial environment based on the level of national economic development. Bus. Strategy Environ. 2020, 29, 1007-1020. [CrossRef]

92. Grimaldi, R.; Kenney, M.; Siegel, D.S.; Wright, M. 30 years after Bayh-Dole: Reassessing academic entrepreneurship. Res. Policy 2011, 40, 1045-1144. [CrossRef]

93. Heinonen, J.; Hytti, U.; Cooney, T.M. The context matters. Understanding the evolution of Finnish and Irish entrepreneurship policies. Manag. Res. Rev. 2010, 33, 1158-1173. [CrossRef]

94. Farinha, L.; Lopes, J.; Bagchi-Sen, S.; Renato, J.; Oliveira, J. Entrepreneurial dynamics and government policies to boost entrepreneurship performance. Socio-Econ. Plan. Sci. 2020, 72, 100950. [CrossRef]

95. Di Foggia, G.; Arrigo, U. The political economy of public spending on Italian rail transport: A European view. J. Appl. Econ. Sci. 2016, 11, 192-206.

96. Friedl, C.; Reichl, J. Realizing energy infrastructure projects. A qualitative empirical analysis of local practices to address social acceptance. Energy Policy 2016, 89, 184-193. [CrossRef]

97. Obaji, N.O.; Olugu, M.U. The role of government policy in entrepreneurship development. Sci. J. Bus. Manag. 2014, 2, 109-115. [CrossRef]

98. Mintrom, M.; Norman, P. Policy entrepreneurship and policy change. Policy Stud. J. 2009, 37, 649-667. [CrossRef]

99. Hoogendoorn, B.; Van der Zwan, P.; Thurik, R. Sustainable entrepreneurship: The role of perceived barriers and risk. J. Bus. Ethics 2019, 157, 1133-1154. [CrossRef]

100. Ejelöv, E.; Nilsson, A. Individual factors influencing acceptability for environmental policies: A review and research agenda. Sustainability 2020, 12, 2404. [CrossRef]

101. Wu, Y.J.; Yuan, C.H.; Pan, C.I. Entrepreneurship education: An experimental study with information and communication technology. Sustainability 2018, 10, 691. [CrossRef]

102. Davari, A.; Farokhmanesh, T. Impact of entrepreneurship policies on opportunity to startup. Manag. Sci. Lett. 2017, 7, 431-438. [CrossRef]

103. Pinkse, J.; Groot, K. Sustainable entrepreneurship and corporate political activity: Overcoming market barriers in the clean energy sector. Entrep. Theory Pract. 2015, 39, 633-654. [CrossRef]

104. Block, J.; Sandner, P.; Spiegel, F. How do risk attitudes differ within the group of entrepreneurs? The role of motivation and procedural utility. J. Small Bus. Manag. 2015, 53, 183-206. [CrossRef]

105. Su, Y.; Zhu, Z.; Chen, J.; Jin, Y.; Wang, T.; Lin, C.L.; Xu, D. Factors influencing entrepreneurial intention of university students in China: Integrating the perceived university support and theory of planned behavior. Sustainability 2021, 13, 4519. [CrossRef]

106. Armitage, C.J.; Conner, M. Efficacy of the theory of planned behaviour: A meta-analytic review. Br. J. Soc. Psychol. 2001, 40, 471-499. [CrossRef]

107. Kallgren, C.A.; Reno, R.R.; Cialdini, R.B. A focus theory of normative conduct: When norms do and do not affect behavior. Pers. Soc. Psychol. Bull. 2000, 26, 1002-1012. [CrossRef]

108. Martínez-González, J.A.; Parra-López, E.; Barrientos-Báez, A. young consumers' intention to participate in the sharing economy: An integrated model. Sustainability 2021, 13, 430. [CrossRef]

109. Young, P. The evolution of social norms. Annu. Rev. Econ. 2015, 7, 359-387. [CrossRef]

110. Legros, S.; Cislaghi, B. Mapping the social-norms literature: An overview of reviews. Perspect. Psychol. Sci. 2020, 15, 62-80. [CrossRef] 
111. Burrus, J.; Moore, R. The incremental validity of beliefs and attitudes for predicting mathematics achievement. Learn. Individ. Differ. 2016, 50, 246-251. [CrossRef]

112. Fang, W.T.; Ng, E.; Wang, C.M.; Hsu, M.L. Normative beliefs, attitudes, and social norms: People reduce waste as an index of social relationships when spending leisure time. Sustainability 2017, 9, 1696. [CrossRef]

113. Hong, I.B. Social and personal dimensions as predictors of sustainable intention to use facebook in Korea: An empirical analysis Sustainability 2018, 10, 2856. [CrossRef]

114. Christensen, P.N.; Rothgerber, H.; Wood, W.; Matz, D.C. Social norms and identity relevance: A motivational approach to normative behavior. Pers. Soc. Psychol. Bull. 2004, 30, 1295-1309. [CrossRef]

115. Tomczyk, D.; Lee, J.; Winslow, E. Entrepreneurs' personal values, compensation, and high growth firm performance. J. Small Bus. Manag. 2013, 51, 66-82. [CrossRef]

116. Maresch, D.; Harms, R.; Kailer, N.; Wimmer-Wurm, B. The impact of entrepreneurship education on the entrepreneurial intention of students in science and engineering versus business studies university programs. Technol. Forecast. Soc. Chang. 2016, 104, 172-179. [CrossRef]

117. Jahanshahi, A.A.; Brem, A.; Bhattacharjee, A. Who takes more sustainability-oriented entrepreneurial actions? The role of entrepreneurs' values, beliefs and orientations. Sustainability 2017, 9, 1636. [CrossRef]

118. Sotiropoulou, A.; Papadimitriou, D.; Maroudas, L. Personal values and typologies of social entrepreneurs. The case of Greece J. Soc. Entrep. 2021, 12, 1-27. [CrossRef]

119. Usman, B.; Yenita. Understanding the entrepreneurial intention among international students in Turkey. J. Glob. Entrep. Res. 2019, 9, 10-32. [CrossRef]

120. Kim, S.H.; Seock, Y.K. The roles of values and social norm on personal norms and proenvironmentally friendly apparel product purchasing behavior: The mediating role of personal norms. J. Retail. Consum. Serv. 2019, 51, 83-90. [CrossRef]

121. Dalila, D.; Latif, H.; Jaafar, N.; Aziz, I.; Afthanorhan, A. The mediating effect of personal values on the relationships between attitudes, subjective norms, perceived behavioral control and intention to use. Manag. Sci. Lett. 2020, 10, 153-162. [CrossRef]

122. Cho, H.; Lee, J. The influence of self-efficacy, subjective norms, and risk perception on behavioral intentions related to the H1N1 flu pandemic: A comparison between Korea and the US Hichang. Asian I. Soc. Psychol. 2015, 18, 311-324. [CrossRef]

123. Fornara, F.; Pattitoni, P.; Mura, M.; Strazzera, E. Predicting intention to improve household energy effciency: The role of valuebelief-norm theory, normative and informational influence, and specific attitude. J. Environ. Psychol. 2016, 45, 1-10. [CrossRef]

124. Tamar, M.; Wirawan, H.; Bellani, E. The Buginese entrepreneurs; the influence of local values, motivation and entrepreneurial traits on business performance. J. Enterprising Communities 2019, 13, 438-454. [CrossRef]

125. Brändle, L.; Berger, E.S.C.; Golla, S.; Kuckertz, A. I am what I am-How nascent entrepreneurs' social identity affects their entrepreneurial self-efficacy. J. Bus Ventur. Insights 2018, 9, 17-23. [CrossRef]

126. Zhang, J.; Huang, J. Entrepreneurial self-efficacy mediates the impact of the post-pandemic entrepreneurship environment on college students' entrepreneurial intention. Front. Psychol. 2021, 12, 643184. [CrossRef]

127. Newman, A.; Obschonka, M.; Schwarz, S.; Cohen, M.; Nielsen, I. Entrepreneurial self-efficacy: A systematic review of the literature on its theoretical foundations, measurement, antecedents, and outcomes, and an agenda for future research. J. Vocat. Behav. 2019, 110, 403-419. [CrossRef]

128. Bandura, A. Self-efficacy and health behavior. In Cambridge Handbook of Psychology, Health and Medicine; Baum, A., Newman, S., Wienman, J., West, R., McManus, C., Eds.; Cambridge University Press: Cambridge, UK, 1997; pp. 160-162.

129. Wei, J.; Chen, Y.; Zhang, Y.; Zhang, J. How does entrepreneurial self-efficacy influence innovation behavior? Exploring the mechanism of job satisfaction and Zhongyong Thinking. Front. Psychol. 2020, 11, 708. [CrossRef]

130. Caines, V.; Earl, J.K.; Bordia, P. Self-employment in later life: How future time perspective and social support influence selfemployment interest. Front. Psychol. 2019, 10, 448. [CrossRef]

131. Asimakopoulos, G.; Hernández, V.; Miguel, J.P. Entrepreneurial intention of engineering students: The role of social norms and entrepreneurial self-efficacy. Sustainability 2019, 11, 4314. [CrossRef]

132. Hussain, I.; Nazir, M.; Hashmi, S.B.; Shaheen, I.; Akram, S.; Waseem, M.A.; Arshad, A. Linking green and sustainable entrepreneurial intentions and social networking sites; the mediating role of self-efficacy and risk propensity. Sustainability $\mathbf{2 0 2 1}$ 13, 7050. [CrossRef]

133. Anwar, I.; Jamal, M.T.; Saleem, I.; Thoudam, P. Traits and entrepreneurial intention: Testing the mediating role of entrepreneurial attitude and self-efficacy. J. Int. Bus. Entrep. Dev. 2021, 13, 40-60. [CrossRef]

134. Dölarslan, E.A.; Koçak, A.; Walsh, P. Perceived Barriers to Entrepreneurial Intention: The Mediating Role of Self-Efficacy. J. Dev. Entrep. 2020, 25, 1-23. [CrossRef]

135. Li, C.; Bilimoria, D.; Wang, Y.; Guo, X. Gender role characteristics and entrepreneurial self-efficacy: A comparative study of female and male entrepreneurs in China. Front. Psychol. 2020, 11, 585803. [CrossRef]

136. To, C.K.M.; Guaita-Martínez, J.M.; Orero-Blat, M.; Chau, K.P. Predicting motivational outcomes in social entrepreneurship: Roles of entrepreneurial self-efficacy and situational fit. J. Bus. Res. 2020, 121, 209-222. [CrossRef]

137. Yang, M.M.; Li, T.; Wang, Y. What explains the degree of internationalization of early-stage entrepreneurial firms? A multilevel study on the joint effects of entrepreneurial self-efficacy, opportunity-motivated entrepreneurship, and home-country institutions. J. World Bus. 2020, 55, 101114. [CrossRef] 
138. Santos, G.; Silva, R.; Rodrigues, R.G.; Marques, C.; Leal, C. Nascent entrepreneurs' motivations in European economies: A gender approach using GEM data. J. Glob. Mark. 2017, 30, 122-137. [CrossRef]

139. Peterson, M. Modeling country entrepreneurial activity to inform entrepreneurial marketing research. J. Bus. Res. 2020, 113, 105-116. [CrossRef]

140. Yong, A.G.; Pearce, S. A beginner's guide to factor analysis: Focusing on exploratory factor analysis. Tutor. Quant. Methods Psychol. 2013, 9, 79-94. [CrossRef]

141. Hair, J.F.; Risher, J.J.; Sarstedt, M.; Ringle, C.M. When to use and how to report the results of PLS-SEM. Eur. Bus. Res. 2019, 31, 2-24. [CrossRef]

142. Jarvis, C.B.; MacKenzie, S.B.; Podsakoff, M. A critical review of construct indicators and measurement model misspecification in marketing and consumer research. J. Consum. Res. 2003, 30, 199-218. [CrossRef]

143. Buhalis, D.; Parra-López, E.; Martínez-González, J.A. Influence of young consumers' external and internal variables on their e-loyalty to tourism sites. J. Destin. Mark. Manag. 2020, 15, 100409. [CrossRef]

144. Ali, F.; Rasoolimanesh, S.M.; Sarstedt, M.; Ringle, C.M.; Ryu, K. An assessment of the use of partial least squares structural equation modeling (PLS-SEM) in hospitality research. Int. J. Contemp. Hosp. Manag. 2018, 30, 514-538. [CrossRef]

145. Fornell, C.; Larcker, D. Evaluating structural equation models with unobservable variables and measurement error. J. Mark. Res. 1981, 18, 39-50. [CrossRef]

146. Chin, C.H.; Lo, M.C.; Razak, Z.; Pasbakhsh, P.; Mohamad, A.A. Resources confirmation for tourism destinations marketing efforts using PLS-MGA: The moderating impact of semirural and rural tourism destination. Sustainability 2020, 12, 6787. [CrossRef]

147. Sarstedt, M.; Ringle, C.M.; Smith, D.; Reams, R.; Hair, J.F. Partial least squares structural equation modeling (PLS-SEM): A useful tool for family business researchers. J. Fam. Bus. Strategy 2014, 5, 105-115. [CrossRef]

148. Pérez-Suárez, M.; Sánchez-Torné, I. El impacto de la educación en la intención emprendedora de los estudiantes del grado de economía. Rev. Estud. Empresariales 2019, 1, 22-40. [CrossRef]

149. Nechaev, A.S.; Antipina, O.V. Assessing the innovation attractiveness of areas: Problems and solutions. J. Adv. Res. Law Econ. 2016, 7, 561-571.

150. Sihombing, S.O. Predicting the relationship between values, attitude and intention to quit: An empirical examination of Indonesian micro entrepreneurs. J. Soc. Sci. Res. 2018, 6, 571-575. [CrossRef]

151. Choongo, P.; Paas, L.J.; Masurel, E.; Van Burg, E.; Lungu, J. Entrepreneurs' personal values and CSR orientations: Evidence from SMEs in Zambia. J. Small Bus. Entrep. 2019, 26, 545-570. [CrossRef]

152. Henao-García, E.; Arias-Pérez, J.; Lozada-Barahona, N. Innovation research based on global entrepreneurship monitor (gem) project: Review of the last decade. Mediterr. J. Soc. Sci. 2017, 8, 131-141. [CrossRef]

153. Ringle, C.M.; Sarstedt, M. Gain more insight from your PLS-SEM results: The importance-performance map analysis. Ind. Manag. Data Syst. 2016, 116, 1865-1886. [CrossRef]

154. Hair, J.; Hult, G.; Ringle, C.; Sarstedt, M. A Primer on Partial Least Squares Structural Equations Modeling (PLS-SEM), 2nd ed.; SAGE: Los Angeles, CA, USA, 2017; pp. 1-384.

155. Hair, J.F.; Sarstedt, M.; Ringle, C.M.; Gudergan, S.P. Advanced Issues in Partial Least Squares Structural Equations Modeling (PLS-SEM); Sage: Thousand Oaks, CA, USA, 2018; pp. 1-272.

156. Tailab, M.M.K. Using Importance-performance matrix analysis to evaluate the financial performance of American banks during the financial crisis. SAGE Open 2020, 10, 2158244020902079. [CrossRef]

157. $\mathrm{Su}, \mathrm{C} . \mathrm{H}$.; Cheng, T.W. A sustainability innovation experiential learning model for virtual reality chemistry laboratory: An empirical study with PLS-SEM and IPMA. Sustainability 2019, 11, 1027. [CrossRef]

158. García-Fernández, J.; Fernández-Gavira, J.; Sánchez-Oliver, A.J.; Gálvez-Ruiz, P.; Grimaldi-Puyana, M.; Cepeda-Carrión, G. Importance-Performance Matrix Analysis (IPMA) to evaluate servicescape fitness consumer by genderband Age. Int. J. Environ. Res. Public Health 2020, 17, 6562. [CrossRef]

159. Henseler, J.; Ringle, C.M.; Sarstedt, M. Testing measurement invariance of composites using Partial Least Squares. Int. Mark. Rev. 2016, 33, 405-431. [CrossRef]

160. Cheah, J.H.; Thurasamy, R.; Memon, M.A.; Chuah, F.; Ting, H. Multigroup analysis using smartpls: Step-by-step guidelines for business research. Asian J. Bus. Res. 2020, 10, 1-20. [CrossRef]

161. Schlaegel, C.; Sarstedt, M. Assessing the measurement invariance of the four-dimensional cultural intelligence scale across countries: A composite model approach. Eur. Manag. J. 2016, 34, 633-649. [CrossRef]

162. Henseler, J.; Ringle, C.M.; Sinkovics, R.R. The use of partial least squares path modeling in international marketing. Adv. Int. Mark. 2009, 20, 277-320. [CrossRef]

163. Chin, W.W.; Dibbern, J. An introduction to a permutation based procedure for multi-group PLS analysis: Results of tests of differences on simulated data and a cross cultural analysis of the sourcing of information system services between Germany and the USA. In Handbook of Partial Least Squares: Concepts, Methods and Applications; Esposito, V., Chin, W.W., Henseler, J., Wang, H., Eds.; Springer: Berlin/Heidelberg, Germany, 2010; Volume 2, pp. 171-193.

164. Hair, J.F.; Black, W.C.; Babin, B.J.; Anderson, R.E. Multivariate Data Analysis; Pearson Education Limited: Halow, UK, 2013; pp. 1-734.

165. Sarstedt, M.; Henseler, J.; Ringle, C. Multigroup analysis in Partial Least Squares (PLS) path modeling: Alternative methods and empirical results. Adv. Int. Mark. 2011, 22, 195-218. [CrossRef] 
166. Zhao, H.; Seibert, S.E.; Hills, G.E. The mediating role of self-efficacy in the development of entrepreneurial intentions. J. Appl. Psychol. 2005, 90, 1265-1272. [CrossRef]

167. Liu, X.; Lin, C.; Zhao, G.; Zhao, D. Research on the effects of entrepreneurial education and entrepreneurial self-efficacy on college students' entrepreneurial intention. Front. Psychol. 2019, 10, 869. [CrossRef]

168. Mwiya, B.M.K.; Wang, Y.; Kaulungombe, B.; Kayekesi, M. Exploring entrepreneurial intention's mediating role in the relationship between self-efficacy and nascent behaviour: Evidence from Zambia, Africa. J. Small Bus. Enterp. 2019, 26, 466-485. [CrossRef] 